\title{
The School of Salamanca
}

\author{
A Case of Global Knowledge Production
}

\author{
Thomas Duve
}

What is today known as the "School of Salamanca" emerged in a time of fundamental political, religious, economic, and cultural transformations. Many of these were linked to early modern (proto-)globalisation and its consequences: the Iberian empires were expanding and their territories soon spanned the globe. Europeans encountered territories as well as cultural and political systems they had not known before. At the same time, reformations divided the res publica christiana, leading to huge political turmoil, wars, and the formation of different confessional cultures. The media revolution enabled communication at speeds and scales hitherto unknown and facilitated access to old and an avalanche of new knowledge. Not least because of these changes, early modern republics and monarchies, empires, religious orders, and the Roman Curia refined their techniques of governance. It was in this context that new universities were founded and traditional ones grew, professionalisation increased, and the sciences flourished.

The University of Salamanca, founded in 1218, played a key role in this development, particularly because the Catholic Kings had converted it into their privileged site of knowledge production. In Salamanca, humanists, jurists, cosmographers, theologians, and canonists trained the imperial elite. Here, future bishops, members of the Audiencias, jurists, and missionaries studied the measurement of space and time, the economy, language, faith, law, and justice and injustice. The preeminent scholars of the time came to Salamanca to teach, publishing houses established their officinae in the city, and probably in few places in the empire did so much information about the explorations and discoveries in the Caribbean and the Americas - including the violence, exploitation, and abuses committed by the European invaders - circulate as it did in Salamanca. Missionaries returned to their alma mater, university professors came from New Spain to publish their books, and members of the powerful religious orders sent reports to their monasteries. The Castilian elite asked for advice and a figure no less than the emperor himself repeatedly consulted 
scholars from Salamanca to give their opinion on the most pressing issues of the time.

Thus, in Salamanca more than in any other place in Castile, information from different areas and fields was collected, processed, and integrated into theoretical reflection. Huge treatises were written which became objects of study for generations of students. Many of them were dedicated to questions of law and justice. Often these books saw several editions and were translated, excerpted, and abridged in compendia and summaries. Salamanca seemed and is still often taken to be - synonymous with scientific innovation and knowledge production in the Siglo de Oro Español. It is therefore not by chance that the names of Francisco de Vitoria, Domingo de Soto, Domingo Bañez, Martín de Azpilcueta, Melchor Cano, and Francisco Suárez, all of whom had at some time taught at Salamanca, still to this day stand pars pro toto for a century during which key insights into the natural world, economics, theology, philosophy, as well as law were formulated. The University of Salamanca and its famous "School of Salamanca" have become an important part of the history of theology, philosophy, cosmography, natural sciences, and law. ${ }^{1}$

1 There is an abundant literature on the School of Salamanca and its historical context, and it is of course impossible to list all these works in this introductory chapter. A comprehensive introductory study of the School with many further references for its historical and theological context is Belda Plans, La Escuela de Salamanca y la renovación de la teología en el siglo XVI. Scholars like Barrientos García, Brufau Prats, Pereña, and others have published seminal studies on the School of Salamanca that are indispensable for research on the School. For more references see also three extensive bibliographies on the history of the University of Salamanca and the School: Rodríguez-San Pedro Bezares and Polo Rodríguez, "Bibliografía sobre la Universidad de Salamanca (1800-2007)"; Pena González, Aproximación bibliográfica a la $(s)$ «Escuela(s) de Salamanca»; Ramírez Santos and Egío, Conceptos, autores, instituciones. Ramírez and Egío not only provided an updated systematic bibliography but also included a thoughtful introduction to some of the developments in research over the last decades. Important legal historical studies on the School of Salamanca that furnish specific bibliographies on individual topics include Decock, Theologians and Contract Law. The Moral Transformation of the Ius Commune (ca.1500-1650); Gordley, The Philosophical Origins of Modern Contract Doctrine; Jansen, Theologie, Philosophie und Jurisprudenz in der spätscholastischen Lehre von der Restitution; and Scattola, Krieg des Wissens. For an introduction to the larger context of law and morality in the early modern period from the perspective of legal history, see Decock and Birr, Recht und Moral in der Scholastik der Frühen Neuzeit 1500-1750. There is a huge amount of literature on Salamanca's role in the history of political thought (with Anthony Pagden and Annabel Brett as central reference points), imperial politics, international law, human rights, the discussions about the rights of indigenous peoples, and increasingly also on Salamanca and slavery. Not least the "historical turn in international law" initiated by Martti Koskenniemi has led to a wave of new publications on the School, most of them concentrating on the history of the "rediscovery" of the School in the 19th century and its significance for international law. Important insights into the moral foundations 
It was the same centrality of the University of Salamanca that converted it into a centre of knowledge production which was deeply entangled with other places. Universities and seminaries in Europe, America, and Asia taught according to the methods and, in some cases, also following the statutes of Salamanca. However, as the chapters by González González, Álvarez Sánchez, and Lanza/ Toste in this volume show with great clarity, this also meant that Salamanca's methods were not simply copied but translated - in the broader sense of cultural translation ${ }^{2}$ - into local realities on different continents. Likewise, in Mexico, Manila, and elsewhere, excerpts, copies, rewritings, new manuscripts, and printed books were produced that drew on ideas and practices stemming from Salamanca which created something new in turn. Ultimately, these actors were convinced that - notwithstanding the different places and situations they were living in - they were all subject to universal principles, contributed to their realisation by putting them into practice under a variety of local conditions, and shared a basic consensus about how to proceed in doing so. The chapters of Folch, Cobo, Moutin, Camacho, Egío, and Aspe Armella present case studies of how actors negotiated the tension between universality and locality in New Spain, the Philippines, and in the context of contact with China respectively. Some of the books written in the New World were printed, read, and commented on in Salamanca and so gave rise to new deliberations in the university and the Convent of San Esteban. The letters that teachers received from their former students now serving in America or Iberian Asia and the stories they told when they returned to Salamanca contained rich information and raised questions which theologians tried to answer in their classes and treatises. In other words, communication was not unidirectional: knowledge circulated and was continuously reshaped. Salamanca was an important node

of early modern law and politics have been gained through the works of Paolo Prodi, Adriano Prosperi, and others following them. Although they do not concentrate exclusively on the School of Salamanca, they reveal the importance of moral theology and its practice for the early modern Catholic world. Since the late 197os, Spanish legal historians like Jesús Lalinde Abadía and Bartolomé Clavero have increased our awareness of the importance of religion in early modern Iberian legal history and its colonial contexts. A recent collection on early modern political and social thought with contributions on colonial law and other aspects has now been presented by Tellkamp (ed.), A Companion to Early Modern Spanish Imperial Political and Social Thought and a companion to the School of Salamanca is being prepared by Braun and Astorri (eds.), A Companion to the Spanish Scholastics. For a general survey of the history of the period, see Bouza, Cardim, and Feros, The Iberian World and Barreto Xavier, Palomo, and Stumpf (eds.), Monarquías Ibéricas.

2 In this article, the term "cultural translation" is used in the broad sense it has acquired in cultural studies. For a full discussion of this, see Duve, "Pragmatic Normative Literature". 
in a huge web of places in which normative knowledge was produced. ${ }^{3}$ It is this global perspective on knowledge production in the Iberian worlds that this book wants to explore. ${ }^{4}$

Normative knowledge, however, is not only about theory, ideas, principles, or doctrines: it also comprises practices. It is, as has been expressed for a modern context, "an activity of mind, a way of doing something with the rules and cases and other materials of law, an activity that is itself not reducible to a set of directions or any fixed description. It is a species of cultural competence, like learning a language." ${ }^{5}$ The same applies - to an even greater degree - to the early modern world, which is why it was the mode of reasoning that was taught and practiced in Salamanca, and the way in which concrete cases were resolved according to it, that shaped the way justice was administered in many places. Wherever a missionary, priest, bishop, or even a judge or crown official who had studied in Salamanca or read books from there exercised his office, he produced new normative statements drawing on what he had learned in or from Salamanca. The analyses of collections of decisions of judicial bodies, declarations of bishops, practices of teaching, and the writing of opinions about central problems of colonial life (such as marriage, restitution, and just war) in the contributions of Aspe Armella, Camacho, Cobo, Egío, Folch, Moutin, and Lanza/Toste respectively, point to these pragmatic contexts of

3 Within the extensive debate about "information" and "knowledge" and their respective definitions, I have opted for a distinction between the terms that conceives of information as the basic unit, as data with a general relevance and purpose. Information is converted into knowledge as soon as it is contextualised and integrated into a field of action, opening up possibilities for action. Knowledge can therefore be understood as the entirety of the propositions that the members of a group consider to be true or which are considered to be true in a sufficient amount of texts produced by members of this group, comprising all kind of patterns of thought, orientation and action. It comprises also implicit knowledge embedded in practices and organisational routines; on the different definitions, see for example Neumann, "Kulturelles Wissen", 811 and Wehling, "Wissensregime". My definition is narrower than the one used by Renn and Hyman, "The Globalization of Knowledge in History: An Introduction", 21-22, who defined knowledge as the capacity of an individual, group, or society to solve problems and to mentally anticipate the necessary actions; they provided an interesting list of forms of knowledge representations and forms of transmission. For a systematic overview, see also Abel, "Systematic Knowledge Research". In the following discussion, "normative" knowledge refers to knowledge as "positively labelled possibilities", a definition developed by Christoph Möllers in Möllers, Die Möglichkeit der Normen. On these aspects, see Duve, "Pragmatic Normative Literature".

4 For the ideas underlying the book project, see the working paper sent to the authors with the invitation to participate and discuss their contributions in a workshop held in Buenos Aires in 2018, Duve, "La Escuela de Salamanca: ¿un caso de producción global de conocimiento?”.

5 White, "Legal Knowledge", 1399. 
the production of normative knowledge. It was - as this introductory chapter seeks to highlight - the combination of the School's dynamic intellectual and scientific development and its essentially pragmatic character, aiming at the cura animarum, that is central to understanding the School. It might well have been precisely this combination of theory and practice that contributed to the School of Salamanca's world-wide impact on the formation of a language of normativity and normative practices, irrespective of whether we see the School as part of oppressive legal imperialism or as the beginnings of cosmopolitan law - or, indeed, as both. ${ }^{6}$

This worldwide presence and translation of normative knowledge which was developed in Salamanca, the interconnectedness between Salamanca and other places, and the pragmatic orientation of its method(s) of reasoning raise important questions.

Firstly, they make us wonder what the defining criteria of the "School of Salamanca" might be and how to decide who should be counted a member of the School, not least in geographic terms. Should they be only those who had learned or taught Thomistic theology at Salamanca, as some scholars maintain? However, if one restricts the School geographically to Salamanca, how should one classify the work done in Coimbra and Évora? Would Martín de Azpilcueta, who first wrote his bestselling Manual de Confessores in Coimbra where he had been sent from Salamanca, count as a member of the School? And how should one classify what was taught and written in Manila, or Mexico, or in seminaries and colleges in Córdoba del Tucumán by scholars who had studied in Salamanca and applied what they had learned there? Or teachings or writings of those who had never touched Castilian soil but were deeply immersed in Salamanca-style thinking and put it into practice? The chapters in this volume show that there are good reasons to integrate them into a joint analysis together with those "Spanish" authors traditionally considered to be members of the School.

And why - to raise further questions resulting from the pragmatic orientation of early modern moral theology as it was practiced in Salamanca - do we define the School as a group of authors and not as a community of practices? Why do we not include their judgements in individual cases, in both the forum externum and the forum internum, or their opinions and practical advice into the set of sources that make up the School? What idea of the School

6 The significance of the political language is emphasised both by scholars who highlight the contribution of Salamanca to international law in a more defensive - or even in some cases hagiographic - manner and by those who are taking a more critical perspective. For a balanced assessment, see Koskenniemi, "Empire and International Law". 
of Salamanca underlies the historiography's nearly exclusive concentration on the big systematic treatises and the general neglect of the many small books and pragmatic literature? Was it not the case that Salamanca become so famous precisely because of deliberations on practical issues, such as the legitimacy of the conquest or the respective powers of the pope and the emperor? Did it not become so influential because of thousands of acts of producing a normative statement - a judgment, an opinion, a canon in a Church Council - which were pronounced in accordance with the teachings and practices learned in Salamanca and elsewhere?

Whilst some of these questions have been intensely discussed, surprisingly few of them have been the subject of critical reflection. ${ }^{7}$ However, behind them lies a general problem that is important for the study of the School of Salamanca but which also reaches far beyond it: the conundrum of how to analyse and classify an intellectual phenomenon like the "School of Salamanca" that was culturally translated under the conditions of European expansion and the media revolution in many places all over the world. The suggestion made in this chapter is to understand the School of Salamanca not as a group of authors in one place, but as the denomination of a specific mode of producing normative knowledge, as a communicative process that was performed by a multitude of actors. Put simply, the "School of Salamanca" was not a group of authors but a cultural practice, a specific mode of participating in the communicative system dedicated to normativity. ${ }^{8}$

To demonstrate this I will not start with the theoretical and methodological assumptions underlying this perspective, ${ }^{9}$ but instead concentrate on the

The definition of the school has long been the subject of scholarly debate, see, for example, Belda Plans, La Escuela de Salamanca y la renovación de la teología en el siglo XVI, 147-206; Belda Plans, "Hacia una noción crítica"; Barrientos García, "La teología"; Barrientos García, "La Escuela de Salamanca: desarollo y caracteres”; Bermejo, “¿Escuela de Salamanca y Pensamiento hispánico?”; Brufau Prats, La Escuela de Salamanca ante el descubrimiento del Nuevo Mundo, 123-124; Zorroza, "Hacia una delimitación de la Escuela de Salamanca"; and Martín Gómez, "Francisco de Vitoria y la Escuela Ibérica de la Paz".

8 On the need to open up the state-centred and legalistic concept of "law" to include other normative spheres, see Duve, "Von der Europäischen Rechtsgeschichte", "Was ist Multinormativität?", and "Global Legal History: Setting Europe in Perspective".

9 The methodological assumptions underlying this perspective are developed in a dialogue between the still emerging field of the history of knowledge and legal theoretical approaches that understand law as a communicative system. For a general introduction to the history of knowledge and for further references, see Burke, What is the History of Knowledge? A good introduction to the field's current state of research is provided by Renn, "From the History of Science "; Daston, "The History of Science "; and Müller-Wille, Reinhardt, and Sommer, "Wissenschaftsgeschichte und Wissensgeschichte". On the globalisation of knowledge, see Renn (ed.), The Globalization of Knowledge, especially Renn 
classical authors and texts of the School and its historiography to show how, in the School of Salamanca, theory, pragmatic orientation, and a certain way of acting, understood as "practices" in the praxeological sense, were inseparably intertwined $(3,4)$. For this reason, the School can be seen as an epistemic community and a community of practice, characterised by a specific mode of producing normative knowledge (5). The knowledge-historical perspective taken by this approach also enables us to understand the School of Salamanca as a case of global knowledge production, shifting our attention away from supposed origins, authors, and places, to understanding and analysing it as one sphere in the multidirectional, complex processes of communication about normativity in the early modern period $(6,7)$. Before engaging in this, however, it seems necessary to ask how the notion of the "School of Salamanca" emerged and what this term signified when it was first used, as well as the path dependencies that might have resulted from this initial understanding of the School $(1,2)$.

\section{Constructing the "School of Salamanca"}

Without aiming to reconstruct the entire development of the historiography on the School of Salamanca, ${ }^{10}$ it seems important to emphasise that, even though the immediate students of Vitoria already recognised him as their teacher and clearly had the idea of belonging to a school, ${ }^{11}$ it was only in the late 19th century that the term "School of Salamanca" was coined and came to be presented as an important moment in the history of European political and legal thought, with Francisco de Vitoria as its most important representative and international law as its most famous object. The reasons for this

and Hyman, "The Globalization of Knowledge in History: An Introduction". On the potential for fruitful dialogue between global legal history and the history of knowledge, see Renn, "The Globalization of Knowledge in History and its Normative Challenges". The methodological assumptions underlying the analysis presented here are close - and in fact owe much - to the work of A. M. Hespanha, see Hespanha, "Southern Europe". The combination of the concept of translation with an evolutionary perspective presented here was inspired not least by the writings of H.P. Glenn and his conceptualisation of "legal tradition", see Duve, "Legal traditions" for a more extensive discussion of this.

10 For a more detailed discussion, see Duve, "The School of Salamanca: a legal historical perspective".

11 See, for example, how Melchor Cano created the idea of being part of a school led by Vitoria, Cano, De locis Theologicis, Liber duodecimus, Prooemium, fol. 385, "Fratrem Franciscum Victoria [...] dicere audivi postqua[m] ab illi[us] schola discessi [...]”. 
rediscovery are manifold. ${ }^{12}$ The late 19th-century Vitoria-renaissance in Spain was part of an attempt to emphasise the Spanish contribution to the development of European science. It was Eduardo Hinojosa y Naveros, often considered the founding father of Spanish legal history, who, on the occasion of his admission to the Real Academia de la Historia in Madrid in 1889 - introduced by Marcelino Menéndez y Pelayo, the famous author of La Ciencia Española-, gave a public lecture on the significance of Francisco de Vitoria for the emergence of international law as a scholarly discipline. ${ }^{13}$ This new field saw a remarkably dynamic evolution during the 188 os and it was of the utmost importance for Spain where new university chairs, journals, and institutes for the emerging discipline were being founded, not least because of the need to better understand Spain's position in the recent and still enduring conflicts with and between its former colonies and other European powers. In his presentation at the Academia, Hinojosa highlighted a series of aspects of Vitoria's work, in particular what he called Vitoria's positivist scientific method, the foundation of Vitoria's legal thought in Aquinas's teachings, and his uniting legal and theological studies. For Hinojosa, studying Francisco de Vitoria meant drawing attention to the Spanish contribution to European cultural heritage in answer to those who, according to Hinojosa, kept denying Spain its proper place in this history. ${ }^{14}$

With his attempt to highlight Vitoria as the "father of international law" as Vitoria was explicitly called by Menéndez y Pelayo on the same occasion Hinojosa was part of a wider movement searching for the historical foundations of international law that was taking place not only in Spain. ${ }^{15}$ More and more jurists, also outside of Spain, pointed to the Salamantine theologians' vital role in the discipline's history as predecessors to Hugo Grotius. The Belgian scholar Ernest Nys did so from the early 1880s onwards and, more than three decades later, published Vitoria's famous Relectiones in $1917 .{ }^{16}$ In the US, James Brown Scott produced an English translation of Francisco de Vitoria's De Indis recenter inventis and De iure belli in 1917, and, following other studies,

\footnotetext{
12 On the history of the historiography and for further references, see Duve, "Rechtsgeschichte und Rechtsräume: wie weit reicht die Schule von Salamanca?".

13 Hinojosa y Naveros, Discursos leídos ante la Real Academia de la Historia. On Hinojosa, see Martínez Neira and Ramírez Jerez, Hinojosa en la Real Academia, which includes Hinojosa's text Influencia que tuvieron en el derecho público de su patriay singularmente en el derecho penal los filósofos y teólogos españoles anteriores a nuestro siglo (189o), 105-226.

14 Hinojosa y Naveros, Discursos leídos ante la Real Academia de la Historia, 52.

15 Generally for this period, see Koskenniemi, The Gentle Civilizer of Nations; for the Spanish context, see Rasilla del Moral, In the Shadow of Vitoria.

Nys, Le droit de la guerre et les précurseurs de Grotius.
} 
published his monograph, The Spanish Origin of International Law. Francisco de Vitoria and his Law of Nations, in $1932 .{ }^{17}$ Scholars of theology and philosophy contributed a series of studies on Vitoria to this first renaissance, particularly in the context of Spanish neo-scholasticism. Luis G. Alonso Getino published various pieces in the journal La Ciencia Tomista, which had been founded in 1914, and some of his writings were later integrated into a new series, Biblioteca internacionalista Francisco de Vitoria. ${ }^{18}$ It was in this general context, and more specifically in the attempts to re-found philosophical and theological Thomism, that the term "School of Salamanca" seems to have first been used. ${ }^{19}$

Obviously, this engagement with Vitoria and the School of Salamanca was also part of the wider discussion about international law that intensified during and after WWI as well as of the pan-American movements and their search for intellectual foundations, which had been gaining strength since 19oo. It was accompanied by research on Spanish humanism and the history of Spanish scholasticism broadly defined that flourished in the interwar period: in Paris, Marcel Bataillon's Erasme et l'Espagne appeared in $1937,{ }^{20}$ and in Rome a year later, R.G. Villoslada's La Universidad de París durante los estudios de Francisco de Vitoria. In Salamanca, important editions of sources were prepared, firstly by Vicente Beltrán de Heredia, who, from 1932 onwards, began to publish the notes of students on Vitoria's ordinary lectures on the Summa. ${ }^{21}$ A small 1939 biographical and bibliographic monograph about Vitoria written by Beltrán de Heredia, the leading scholar on the School in those turbulent times, became an important point of reference. That this study appeared as volume 14 in a Colección pro ecclesia et patria points to the tenor of much of the research on Francisco de Vitoria and the School of Salamanca during the Franco period.

17 Scott, The Catholic Conception of International Law and The Spanish Origin of International Law. On Scott, see Scarfi, The Hidden History of International Law in the Americas.

18 Alonso Getino, El Maestro Fr. Francisco de Vitoria.

19 The German theologian Martin Grabmann seems to have been the first to use the term "School of Salamanca" in an essay published in 1917 which commemorated the 3ooth anniversary of the death of Francisco Suárez (Grabmann, "Die Disputationes metaphysicae des Franz Suarez", 29-73). He drew on earlier research done by the German Jesuit Ehrle in the Vatican library. In Grabmann's essay, the term "Theologenschule zu Salamanca" ("school of theologians at Salamanca") first appeared in a footnote; later in the text he referred to studies on the "School of Salamanca and on Spanish and Portuguese scholasticism". The term was later used in the context of economic history, see Grice-Hutchinson, "El concepto de la Escuela de Salamanca".

$20 \quad$ Bataillon, Erasme et l'Espagne.

21 On the manuscripts, see Beltrán de Heredia, Los manuscritos del maestro fray Francisco de Vitoria. 
Many of these publications concentrated on highlighting the contribution of Spanish authors to the establishment of an international law that was intended to provide peace (one series of publications is even called Corpus Hispanorum de Pace) and spread Christian values in a world in which Hispanismo had played and was supposed to play an important role. ${ }^{22}$ In a way, many authors still fought against the so-called Black Legend, if now under different political circumstances. ${ }^{23}$ Authors from Salamanca took the lead in this, many of them experts in the history of the university and the Spanish history of the Dominican Order, and some - like Beltrán de Heredía were themselves members of that order. It was, therefore, not surprising that most of the research concentrated on Salamanca and the Dominicans, not least because the archives in Salamanca contained (and still contain) vast quantities of documentation to be explored. Those scholars saw Salamanca as the centre that had exerted its influence over many places all over the world. ${ }^{24}$

\section{Deconstructing the "School of Salamanca"}

Looking at this picture, notwithstanding the inevitable generalisations, we might say that the leading narrative from the 1880s until the end of the Franco regime put Francisco de Vitoria at the beginning of an intellectual movement whose exclusive location had been Salamanca and which had been profoundly scientific, Dominican, and Spanish. For most of the researchers during the first century of the Vitoria renaissance, and even some today, the main achievement of the School lay in its contribution to the formation of a science of international law and a renewal of (moral) theology that was grounded in a particular union of the Spanish nation, Christian faith, and Thomistic theology

22 For a discussion from the perspective of the history of universities, see González in this volume. A certain apologetic tendency is still visible in the titles of major publications, not least that of the publication series Corpus Hispanorum de Pace; a selection of essays that develop this perspective can be found in Ramos (ed.), Francisco de Vitoriay la Escuela de Salamanca.

23 On the current state of this issue, see contributions in Villaverde and Castilla Urbano (eds.), La sombra de la leyenda negra.

24 There has been an increasing number of studies on what is called the proyección Americana of Salamanca, see for example Cerezo, "Influencia de la Escuela de Salamanca"; on the proyección, see also Barrientos García, Repertorio de moral económica (1526-1670), 77-84 and Rodríguez-San Pedro Bezares and Polo Rodríguez (eds.), La Universidad de Salamanca y su confluencias americanas. 
and philosophy. The School consisted of authors, had a centre, and influenced the peripheries.

From a legal historiographical perspective, Hinojosa and his contemporaries' presentation of Vitoria as the founding father of international law, and therefore a major Spanish contribution to the history of European legal scholarship, was a way of integrating the School into the big narrative of European legal history as a history of "scientification" (Verwissenschaftlichung) - a historical narrative of European legal history dating back to the Historical School of Law that Hinojosa had studied extensively when he was in Germany and brought with him to Spain. Particularly in 2oth-century German-speaking legal historical research, the School of Salamanca began - after some early work by Josef Kohler ${ }^{25}$ - to be studied more intensively under the influence of Carl Schmitt and then in the context of the brief renaissance of natural law after WWII as a theological contribution to the formation of the modern legal system. ${ }^{26}$ Despite its considerable shortcomings and ideological twists, this approach paved the way for important research on the history of legal reasoning and institutions from this Catholic tradition, which had long been underrated in legal historical scholarship. ${ }^{27}$

Since the 1970s, the dominant narrative on the School outlined above has increasingly been criticised and challenged. ${ }^{28}$ It is now being superseded by a number of different perspectives, including the deconstructive impetus of critical international law historiography, in-depth studies by historians of theology and philosophy, and in still scattered legal history studies. As a result of the latter, it is becoming increasingly clear that Francisco de Vitoria was himself part of a broad intellectual current that had not begun in Salamanca but arrived there with him - which also means that it arrived there later than in Paris, perhaps also later than in Cologne or Louvain. The more Salamantine authors are investigated, the clearer their links to tradition become. Thus, going beyond a local (Salamanca) and national (Spanish) perspective and integrating Salamanca into a broader European and interdisciplinary context as well as abandoning the exclusive concentration on the history of international law has increasingly relativised the School's special status. Hesitantly, but with ever more convincing arguments, the "medieval - modern divide" is

25 Kohler, "Die spanische Naturrechtslehre des 16. und 17. Jahrhunderts".

26 See for example Thieme, "Natürliches Privatrecht und Spätscholastik".

27 See for example Jansen, Theologie, Philosophie und Jurisprudenz; Decock, Theologians and Contract Law.

28 For an example of an early critique, see Lalinde Abadia, "Anotaciones historicistas al iusprivatismo de la segunda escolástica" and "Una ideología para un sistema". 
being overcome in this field, too. ${ }^{29}$ Attention is increasingly being directed to the time before Columbus and to the lines that can be drawn between Vitoria and both earlier and contemporary authors in other places. ${ }^{30}$ The apologetic and sometimes even hagiographic style of writing about Vitoria can still be found, but at the same time there are more and more studies from a postcolonial perspective that consider Vitoria and other thinkers of the School as simply another face of empire and as architects of colonialism and justifiers of exploitation and legal imperialism. ${ }^{31}$

Even Vitoria's unique position in Salamanca is increasingly called into question, albeit not particularly on the grounds of a general scepticism about the search for "inventors" or "founding fathers" in literary and historical studies - a critical perspective astonishingly absent in legal historiography and research on the history of the School of Salamanca. ${ }^{32}$ More than that, a series of individual studies has shown how much Vitoria relied on earlier authors and was embedded in comprehensive discursive contexts - notably with Domingo de Soto, who in the meantime has come to be regarded as the author with the greater impact on subsequent generations. ${ }^{33}$ Many of Vitoria's arguments against the conquest had been advanced by others previously, and many of the inventions attributed to him were firmly rooted in tradition: even what is perhaps considered to be his most famous argument regarding what has been called a ius communicationis is to be found mutatis mutandis in Cicero and Thomas Aquinas. ${ }^{34}$ Therefore, Francisco de Vitoria was doubtless an exceptional figure and an impressive teacher, but, in the final analysis, he was also a pupil of others and an interlocutor for many. ${ }^{35}$ Quite the scholastic, he took

29 On this need, see Muldoon (ed.), Bridging the Medieval-Modern Divide; on late medieval philosophy, see Schmutz, "From Theology to Philosophy"; for medieval expansion to the Canary Islands, see Egío García and Birr, "Before Vitoria: Expansion into Heathen” and "Alonso de Cartagena y Juan López de Palacios Rubios".

30 Fernández-Armesto, Before Columbus; Abulafia, Discovery of Mankind. For a legal historical perspective, see Pérez Voituriez, Problemas jurídicos internacionales de la conquista de Canarias and Olmedo Bernal, El dominio del atlántico en la baja edad media.

31 An often-cited text is Anghie, Imperialism, Sovereignty and the Making of International Law; for a survey of recent postcolonial approaches to the study of the School of Salamanca, see for example Koskenniemi, "Vitoria and Us".

32 On this criticism and its impact on the history of science, see for example Secord, "Knowledge in Transit".

33 See Scattola, "Domingo de Soto e la fondazione della scuola di Salamanca"; Wagner, "Zum Verhältnis von Völkerrecht und Rechtsbegriff bei Francisco de Vitoria"; and Tellkamp, "Vitorias Weg zu den legitimen Titeln der Eroberung Amerikas".

34 Scattola, "Das Ganze und die Teile"; Pagden, "The Christian Tradition".

35 See for example Scattola, "Die Systematik des Natur- und Völkerrechts bei Francisco de Vitoria". 
up the auctoritates, marshalled them with the particular circumstances of his time in mind, and integrated them into a uniform schema of natural and international law in a specific period. ${ }^{36}$ What made him so special was that what he said was politically highly charged and uttered in a historical context of theology marked by conflict and disputes between schools. ${ }^{37}$

What does this critical assessment of the research tradition mean for the notion of a "School of Salamanca"? When the School was basically considered to have been a national contribution to the history of European (legal) scholarship with Salamanca as its exclusive centre, this implicit consensus determined the selection of the relevant sources (the big treatises) that were to be examined, the place that was to be looked at (the University of Salamanca), as well as the perspective of most of the legal historical research that was done (contributions to the history of the "scientification" of law). Due to the general approach of late 19th- and early 2oth-century historical scholarship, intellectual history was basically a history of authors (not of books) in search of origins and founding fathers, not mechanisms of knowledge production. Notwithstanding the great importance of the findings made on the basis of this consensus and from these perspectives - owed in part to scholars whose political frameworks for research we might not share today -, it seems timely to open up our analysis to include other dimensions which were inherent to, and perhaps even characteristic of, the School but that have not yet been studied, not least because of the path dependencies resulting from the historiographical tradition. Two aspects that seem especially important are the School's pragmatic orientation, which has been emphasised by historians of theology but only partially considered in legal historiography, ${ }^{38}$ and its being part of a process of global knowledge production, different aspects of which are explored in the case studies in this volume.

But what might a history of the School of Salamanca written as a history of global - knowledge production that comprises both theory and practice look like? A history that looks far beyond Salamanca: to Mexico, Guatemala, Manila, China, Coimbra, Évora? To understand this, we have to more closely examine the often overlooked deep entanglement and even inseparability of theory and practice in the School of Salamanca.

\footnotetext{
36 Scattola, "Das Ganze und die Teile".

37 On this context see Barrientos García, "La teología" and Quantin, "Catholic Moral Theology, 1550-180o".

38 Juan Belda Plans in particular has insisted on its pragmatic character, see Belda Plans, "Teología práctica y Escuela de Salamanca del siglo XVI"; for a legal historical perspective, see Decock, "From Law to Paradise".
} 
As is well known and has been examined in great detail in the last decades, scholars at the University of Salamanca and the city's Dominican Convent of San Esteban were working on no less a task than reflecting on the order of the world in all its dimensions. The theologians could conceive of this order only as the divine order of being from which everything else - the natural order, the economic order, and the normative order - derived. Since the 1530s, the key work for understanding reality was - particularly for the Dominicans, but not only for them - the Summa Theologiae of Thomas Aquinas. Already during his stay in Paris, Francisco de Vitoria had assisted his teacher, Petrus Crockaert, in preparing an edition of Aquinas's Summa. After his arrival in Salamanca in 1526 , he based his lectures in the most important class, the prima, on it. From then on, the Summa provided the architecture of knowledge, scholasticism the methods and academic practices, and the auctoritates the content of the classes. Many of these auctoritates were contained in the Summa itself, in Aquinas's commentary on Peter Lombard's Sentences - the latter being a famous work that was still widely used -, and in other collections of authorities. In the course of preparing their classes, theologians and canonists from Salamanca worked on their theological and philosophical systems and produced voluminous treatises within a specialised genre dedicated to questions of justice and law that developed out of the tradition of Summa commentaries, of which the treatises De iustitia et iure and De legibus are the most famous examples. ${ }^{39}$ These and other books from Salamanca, particularly some of the "extraordinary" lectures, the famous Relectiones, have been studied by generations of students and make up the core of what is considered to be the most important legacy of the School.

For theologians since the Middle Ages, however, the order of being was above all the one that should guide human conduct. ${ }^{40}$ Salamanca's prominent position as a place of consultation since the days of the Catholic Kings meant that many people turned there, and particularly to the Dominican Convent of San Esteban, with all kinds of moral doubts. A whole series of circumstances contributed to the fact that there was widespread uncertainty about what was

39 On these treatises, see Folgado, "Los tratados De legibus y De iustitia et iure" and Barrientos García, “Los Tratados ‘De Legibus' y ‘De Iustitia et Iure’ en la Escuela de Salamanca de los siglos XVI y XVII".

40 On the emergence of practical ethics in the later Middle Ages and the history of theology, see Mandrella, "Der Dekalog als Systematisierungsschlüssel”; for later casuistry, also in the period of the School of Salamanca, see Müller, "Die Bedeutung des Dekalogs". 
morally doubtful and what was not, what was just or unjust. The early modern information overload had made so many opinions available that orientation was difficult and the Reformations within and outside of the Catholic world, heated controversies between so-called doctores modernos and others, produced contradictory statements on theological dogmas as well as on how to evaluate and judge key issues of social life. Moreover, European expansion across the Atlantic transformed Castile from a backward agrarian economy into the centre of world trade within a few decades as enormous quantities of silver flowed into Seville and a wave of speculation, inflation, and debt followed. Both economic and moral risks proliferated, and people were afraid that certain acts would put the salvation of their souls at risk.

All this gained momentum precisely in the decades between Vitoria's arrival in Salamanca in $15^{26}$ and his death in 1546 . Old but newly relevant questions regarding the legitimacy of particular forms of trade, moneylending, and novel banking instruments had to be resolved. Many of these very mundane questions inspired the School's great treatises. Domingo de Soto's De iustitia et iure, for example, focused on the many issues surrounding the question of "just price". Soto explicitly stated that the practical problems caused by trade and business made him write his multi-volume treatise, ${ }^{41}$ which later went through over 30 editions and is viewed as the central work of at least the first generation of the School of Salamanca. ${ }^{42}$

Precisely because of this pragmatic orientation, Salamanca's scholars not only produced great commentaries on Aquinas's Summa and treatises, such as De iustitia et iure and De legibus, but also pragmatic literature: smaller handbooks for those engaged in normative practice, particularly confession manuals. ${ }^{43}$ These included bestsellers such as the Manual de confessores by Martín de Azpilcueta, an eminently pragmatic book that was written by the most respected canonist and moral theologian of his time, which not only went through 9o editions but was also reworked into summaries, compendia, and

41 Soto, De Iustitia et Iure, Liber VI, 505: "Eo denique destinati operis perventum nobis est, cuius praecipue gratia de illo coepimus cogitare. Haec inquam usurarum, contractuum, cambiorumque ac simoniarum sylva in animum potissime nobis induxit, ut tantam operem molem aggrederemur. See also: Soto, De Iustitia et Iure, Prooemium, 5: [...] peperit tamen humana libido per temporum iniquitatem, parturitque in dies novas fraudulentiae formas, quibus contra ius \& fas suam quisque expleat insatiabilem avaritiam. Quapropter nihil aliud quam operae pretium arbitrandum est si iniqua pacta \& conventa, \& cambia, tamquam adeo multa usurae simoniaeque recentia genera in animum nobis induxerunt, nova de re veteri volumina aedere."

42 See Scattola, "Domingo de Soto e la fondazione della scuola di Salamanca".

43 See on this the contributions in Duve and Danwerth (eds.), Knowledge of the pragmatici. 
epitomes. ${ }^{44}$ The Relectiones too, which generally circulated in manuscript form (although some, but not all, were later printed as well), attracted much attention. In many cases, they were dealing with highly disputed problems of mayor significance. Vitoria's Relectiones on the Indies and on just war are the most famous case, but not the only one. The relectiones of Domingo de Soto and Melchor Cano on sacramental doctrine - the former's only published posthumously, whereas Cano's went through several editions during the author's lifetime alone - dealt with highly charged theological questions of great and direct relevance for daily life.

Even the regular lectures on theology frequently touched upon questions of current practices - and were often openly critical of them. ${ }^{45}$ Vitoria, for example, commented in one of his lectures on theology on the common practice of fulfilling the duty of restitution - a prerequisite to receiving absolution in confession - by acquiring a compositio, part of the so-called "crusader indulgence" (Bulla de la Santa Cruzada), at a fraction of the amount owed. This mode of restitution was offered in cases where one knew that one had to restitute a good acquired illegitimately, but could not find the person to whom it was owed - a frequent occurrence in times of war, sudden deaths, and pilgrimages, not least in the New World, where soldiers and merchants robbed and looted indiscriminately and encomenderos exploited the indigenous population, and then feared for the salvation of their souls. Vitoria called this practice, which was of huge economic importance for both the Church and the Crown, the "biggest joke in the world". And this was not just his personal opinion or a random comment he made in class. Instead, it was the result of a thorough analysis of papal potestas and dominium, which drew on similar to the arguments to those he had employed in his 1539 Relectio de Indis regarding the pope's right to grant the recently discovered territories of the New World to the Spanish Crown. Moreover, from one of his letters we learn that he also practiced as a confessor what he taught in class. In response to a request for advice on the practice of the compositio by acquiring the Bulla de la Cruzada, he wrote, "I do not preach against it [sc. the compositio] [...] but neither do I give absolution to anyone." This is only one of many examples of how everyday problems of political, social, and economic life, the systematic deliberations based on the Summa, and the pastoral office, the cura animarum, were intertwined. ${ }^{46}$

\footnotetext{
44 Bragagnolo, "Managing Legal Knowledge in Early Modern Times".

45 On teaching and academic practices in the faculty of theology in Salamanca since 1560, see the monumental work of Barrientos García, La Facultad de Teología de la Universidad de Salamanca.

On this case, see Duve, “''La mayor burla del mundo'?”.
} 
However, since not only merchants and soldiers but also the emperor, kings, and cardinals consulted the scholars of Salamanca, they also dealt with the big political questions of their time. Expansions, reformations, and wars called for intensive reflection on power, obedience, hierarchy, and heresy, and major works on the history of legal and political thought have been written about these issues. Salamantine scholars took part in the Council of Trent and the many so-called juntas, ad hoc committees instituted by the emperor to consult about particular problems. They wrote expert opinions on the doctrine of justification, the marriage of the English king Henry viII, Erasmianism, the legitimacy of the Castilian presence in the Americas, just war, the baptism of members of indigenous peoples, and slavery. It was above all the positions adopted by Francisco de Vitoria on the moral problems raised by the invasion of the New World that made him - and with him, Salamanca - famous. The issues surrounding the conquest, too, were practical, not merely theoretical, problems. The question moving hearts and minds was no less than whether those involved in the conquest, ranging up to the souls of the emperor himself and his advisers, endangered their salvation.

In short, the authors of the School of Salamanca not only wrote large systematic treatises, they also produced pragmatic literature and responded to specific and concrete individual questions. They did so because of the theological tradition and the practices that emerged from this, especially in the forum internum, which obliged them to inquire into the details of each case to find an adequate answer, and also because consultation was a deeply rooted cultural practice in 16th-century Iberia. At the highest level, this culture of consultation manifested itself in the royal juntas, in the importance of royal confessors, and in institutions such as the Mesa da Consciência e Ordens, established by the Portuguese crown in $1532 .{ }^{47}$ In less exalted spheres, priests and moral theologians were dealing with a multitude of everyday requests for advice. ${ }^{48}$ As confessors, they decided about sins, major or minor; as consultants, they gave their opinion on all matters of daily life. As Francisco de Vitoria emphasised, "We serve God by responding not to cases, but to those who ask in order to alleviate their conscience and who follow the advice they receive". ${ }^{49}$ This prioritising of

47 On the significance of confessors and moral theology for the political culture and governance of Castile, see, for example, Martínez Peñas, El confesor del rey en el Antiguo Régimen and Sosa Mayor, El noble atribulado. On the Mesa da Consciência e Ordens in the Portuguese monarchy, see Marcocci, "Conscience and Empire".

48 See González Polvillo, El gobierno de los otros and O'Banion, The Sacrament of Penance.

49 Vitoria, "Disensiones del reverendo padre maestro fray Francisco de Vitoria", 302: "Y no es servicio de Dios responder a los casos, sino a los que preguntan por sanear sus conciencias y hacen lo que se les dice". 
concrete advice on each single case points to an essential characteristic of the School's modus operandi: each case had to be considered carefully and individually and in its unique context in order for the correct decision to be found, and this decision had to be made in light of existing knowledge about the principles of justice.

This already shows that finding the right answer to a problem was not simply a matter of knowing where to look for the relevant norms but the product of an ars. This ars could only be performed adequately by experts - and, as an ars, could only be learned from teachers, and through integration into a "School" of practice. A brief look at this ars might thus help to illustrate why the reasoning of the School can only be understood adequately if it is considered not just as intertwined with daily life and practice, but as practice.

What can be called an early modern ars inveniendi, the mode of how to reach an adequate answer for a moral doubt, was based on a specific practice of bringing together ratio and auctoritas. ${ }^{50}$ The key for understanding this intellectual operation lies in 16th- and 17th-century theologians' (and jurists') fundamental epistemological assumption that the texts one could draw upon, the auctoritates, did not contain ready-made solutions for all cases. Instead, they were concretisations, and therefore only part of - but also the way to - a higher

$5^{\circ}$ Obviously, the Thomistic method of the School of Salamanca as well as the relation between ratio and auctoritas are complex issues and the manifold positions taken by different authors and generations of scholars cannot be analysed in detail here. The most influential work on the history of moral theology that also discusses these issues is Mahoney, The Making of Moral Theology; see also Theiner on the modern period, Die Entwicklung der Moraltheologie, Vereecke, Storia della teologia morale moderna, and Vidal, Historia de la teología moral. More specifically on Salamanca, the best treatment of these questions from a theological perspective is offered by Belda Plans, La Escuela de Salamanca y la renovación de la teología en el siglo XVI, especially 207-312 (on Thomism) and $619-750$ (on the relation between ratio and auctoritas). The question is closely related to the debate about whether early modern theological casuistry was more prudential or more juridical in character, see Quantin, "A propos des premières Summae confessorum. Théologie et droit canonique". On the plurality of opinions in the slightly later Barockscholastik and early modern probabilism as the intellectual response to the plurality of opinions, see Schüßler, "Meinungspluralismus in Moraltheologie und Kasuistik". On the construction of the legal argument in the field of ius gentium, see Brett, "Sources in the Scholastic Legacy". For a more detailed reconstruction of the early modern way of producing a normative statement, see Duve, "Pragmatic Normative Literature", from which some parts of the following are taken. 
objective truth that could not be accessed directly. In considering a concrete question, therefore, the auctoritates that the author had selected from different repositories - topoi, loci communes - as relevant had to be included in the process of reasoning, often within the framework of a concrete question, a quaestio. Since they formed the point of departure for one's own argumentation, the appropriate and careful compilation and arrangement of the auctoritates were of prime importance. This is why much time and energy were spent on studying the authorities and producing media in which relevant authorities were collected, such as reference works and pragmatic literature.

However, the solutions to specific cases could not be plucked directly from these authorities. They had to be found through a rational process that drew on different auctoritates and critically weighed their applicability and appropriateness for the case under consideration; it was a practice for arriving at the correct choice in the tradition of earlier reflections de electione opinionum. This was the domain of reason, ratio and prudentia. Authorities from both past and current normative production of ecclesiastical or secular rulers were obviously weighty arguments. They showed a way, sometimes even the only way, to the right solution. In certain cases, there was no cause for doubt due to the high degree of authority of certain texts: the solution was inevitably given. But in most cases, the authorities one found could be open to diverging interpretations or even contradict each other. In the end, they were just aids to finding the solution and not the solution as such. Scholars thus developed certain operational rules for the process of producing the right solution: a methodus and a theory of sources and their authoritative value. One can call this a "theory of practice" in the sense of guidelines for the right exercise of this ars. According to this theory, it was necessary to search in different places (loci, topoi) for the normative option whose partial truth seemed most appropriate to the individual case at hand. The philosophical background of this method was early modern - legal, philosophical, and theological - topica and the resulting procedure, the dialectica. The methodus provided specific techniques of interpretation.

Alongside this explicit and formalised theory of practice - the theory of sources, the method - there were also practices of norm production as such, including established patterns of action, conventions, or implicit knowledge about the right way to proceed. Many of these practices were not explicit, perhaps because they were part of a general but silent consensus and could typically be acquired only by integration into a community of practice, for example as a student who was "learning by doing". They were, in no small part, the elements that determined the feeling that certain decisions might be just or unjust for a concrete case, a way of giving a systematic place to what in 19thcentury debates was often simply called the Rechtsgefühl, a way of integrating 
the circumstances of the concrete case into the right decision. Francisco de Vitoria expressed the necessity of knowing the concrete circumstances in one of his responses to generalised questions about the permissibility of certain trading practices, "I don't really want to answer these questions of the money changers unless I know who is asking and why. Many ask only for their own advantage and are delighted if one grants permission. And if they don't like the advice they receive, they ignore it and make fun of the doctrine and its author."51

Historical research on knowledge production has increasingly paid attention to these implicit understandings, the rules of practice, regulatory rationalities, habitus, etc. They can also be considered as an integral part of legal - or normative - knowledge that, by definition, also comprises practices. ${ }^{52}$ They have special importance in a regime of knowledge production that left large margins of discretion to the actors as was the case in 16th- and 17th-century normative reasoning both in law and theology, the two key normative disciplines. Many of these rules of practice were understood as part of the concepts - and, due to their indeterminacy, in a certain way also the black box - of ratio or prudentia. Therefore, it was not by chance that ratio was essential to the interpretation of all authoritative texts, not least Scripture, and so shaped the Salamantine scholars' debates with humanist, Erasmist, and Protestant writers. This is why Francisco de Vitoria stressed in this teaching that ratio was decisive, "non tantum ex auctoritate, sed ratione, utendum esse in theologia" [it is necessary to use not only authority but [also] reason in theology]..$^{53}$

Regarding this book's central question of whether we can understand the School as a historical formation exclusively linked to Salamanca or should rather see it as a case of global knowledge production, it seems important to highlight that it might be, in no small way, these rules of practice, the "practices of practice", and, more concretely, the conviction that one had to look at the circumstances of each case and find a just solution for this specific case, that made up the School. As a group, the members of this School shared not

$5^{1}$ Vitoria, "Disensiones del reverendo padre maestro fray Francisco de Vitoria", 302: "Yo respondo de mala gana a estos casos de cambiadores, sin saber quién los pide y para qué. Porque muchos los preguntan para aprovecharse y alargarse si les dan alguna licencia. Y si algo les dicen contra su interés, dáseles poco y búrlanse de la doctrina y del autor."

$5^{2} \quad$ For a more detailed discussion, see Duve, "Pragmatic Normative Literature".

53 See the comment to the $\mathrm{I}^{\text {a }}$ Pars of the Summa Theologiae, Q. 1, BMP, 78, transcribed in Langella, La ciencia teológica de Francisco de Vitoria (2013), App. v.1., 262-415, quote in articulus octavus, tertio, 36o, "Tertio admonet non tantum ex auctoritate, sed ratione, utendum esse in theologia, quia scientiae humanae sunt quoque a Deo et eas debemus adducere in obsequium Christi." 
only a theory of practice, but also an - often implicit - consensus about how to translate the auctoritates into a just decision for a concrete case. Essential parts of this ars could only be learned by the integration into a community which can be called, in terms taken from the history of knowledge, an epistemic community that was, at the same time, a community of practice. Can we, therefore, imagine the School of Salamanca as such, and what would be its main characteristics?

\section{The School as an Epistemic Community and a Community of Practice}

If we now turn to the Salamanca theologians with these findings in mind, there are some aspects that could be taken into account when exploring the School of Salamanca as an epistemic community in the sense of a group of people with shared knowledge, expertise, beliefs, and also - due to the importance of practices - as a community of practice..$^{54}$

Some could be called more subjective aspects, for example the selfperception of belonging to a school that began with Vitoria. Melchor Cano, who dissented from Vitoria's views in quite a number of cases, is a good example. He not only called Vitoria the "greatest doctor of theology that Spain has been given by God", he also explicitly used the expression of a schola, although his use of this term might have been simply due to the fact that it also served to denominate scholasticism in general, underlining the fact that those following Aquinas saw themselves clearly as part of a diachronic community. ${ }^{55}$

In the same context, Cano also pointed to the characteristically critical spirit within the School. In his De locis theologicis, he reported that in his lectures, Vitoria stressed that one should never accept even Aquinas's views without

54 Epistemic communities are often defined as groups of people who share knowledge, expertise, beliefs, or ways of looking at the world, as a group of professional specialists or a school of thought consisting of persons who share a disciplinary paradigm in the Kuhnian sense, see Cetina Knorr, "Epistemic cultures". In many definitions, the epistemic community only comprises knowledge in a narrow sense, excluding practices. For this reason, it seems helpful to clarify that the School can be considered an epistemic community and also a community of practice. On this distinction, see Duve, "Pragmatic Normative Literature".

55 Cano, De locis Theologicis, Liber duodecimus, Prooemium, fol. 385, "Fratrem Franciscum Victoria Lector optime, eum quem summum Theologiae praeceptorem Hispania dei singulari munere accepit, solitum $[\ldots]$ dicere audivi postqua[m] ab illi[us] schola discessi $[\ldots]$." 
having reflected on the issue oneself. ${ }^{56}$ According to Cano, Vitoria himself had always abided by this principle, and he, Cano, now followed the example of Vitoria. He heeded Vitoria's teachings and exhortations, as he explicitly emphasised, ${ }^{57}$ but he would not swear by the words of his teacher, "Theologo nihil est necesse in cuiusquam iurare leges" [swearing to anyone's laws is not necessary for a theologian] he wrote, alluding to a famous line of Horace. ${ }^{58}$ Vitoria had written something very similar in his foreword to his teacher Petrus Crockaert's edition of Aquinas's Summa..$^{59}$ It is the many mutual references like this one, the fine texture interweaving Aquinas and Vitoria with one's own opinion - and perhaps the emphasis on the ratio against the auctoritates, even if taken from one's own School - that constituted a sense of community. This community did not end at the pillars of Hercules: as Egío points out in his contribution to this volume, writing in New Spain, Alonso de la Vera Cruz considered Vitoria to be "princeps magister [...] olim praeceptor meus" [principal master $[\ldots]$ once my teacher $] .60$

Another important aspect that also contributed to the self-identification of belonging to a "school" was the privileged position the theologians claimed for themselves, not least with regard to jurists and canonists. ${ }^{61}$ Due to the need to deliberate everything that happened sub specie aeternitatis and their obligation to look after the salvation of souls, the cura animarum, theologians felt entitled to give their opinion on basically everything. As Vitoria famously put it, "[T] he task and office of the theologian are so far-reaching that no argument, no consideration, and no topic appears to lie beyond the purview of the theological profession and office." ${ }^{\prime 2}$ Similar statements can be found in Domingo

56 Cano, De locis Theologicis, Liber duodecimus, Prooemium, fol. 385, "Sed admonebat rursum, non oportere sancti doctoris verba sine delectu \& examine accipere [...]."

57 Cano, De locis Theologicis, Liber duodecimus, Prooemium, fol. 385, "[...] quod virum hunc rerum earum omnium ducem optimum sequimur, atque eius praeceptis monitisque paremus."

58 Cano, De locis Theologicis, Liber duodecimus, Prooemium, fol. 385 .

59 See the preface of Francisco de Vitoria in the edition of Aquinas's II $^{\mathrm{a}}-\mathrm{II}^{\mathrm{ae}}$, printed by Claudio Chevalon, Paris, 1512. The text of the preface in this rare edition is transcribed in Langella, La ciencia teológica de Francisco de Vitoria, 102-109, Apéndice I, 104, "in unius auctore verba iurare."

6o See Egío in this volume.

61 On Salamanca as a school of jurists with particular emphasis on the practical dimension, see Alonso Romero, Salamanca, escuela de juristas.

62 Vitoria, De potestate civili: "OFFICIVM, ac munus Theologi tam latè patet, ut nullum argumentum, nulla disputatio, nullus locus alienus uideatur à theologica professione, \& instituto" (https://id.salamanca.school/texts/Wool3:vol1.3.2?format=html). 
de Soto's De iustitia et iure 63 and in the early 17 th century in Francisco Suárez's De legibus, "No one should be surprised if someone who engages in theology concludes that the laws are a subject worthy of critical examination." ${ }^{64}$ This was also how Francisco de Vitoria justified the theologians' competence to give their opinion about the rights of indigenous peoples in the Americas, although, in that specific case, there was also an additional reason: these peoples, he argued, were not subject to the ius humanum, but had to be treated according to the leges divinas. Jurists were therefore simply not qualified to take decisions involving these divine laws, particularly as the forum conscientiae was involved. Only priests were capable of deciding about these issues. ${ }^{65}$

And so, the theologians of Salamanca in general regarded secular and canon law as merely ancillary sciences, not only when deciding on the right solutions to questions such as the treatment of indigenous Americans. One naturally needed to know both, if only because of the practical implications, ${ }^{66}$ as both jurists and canonists emphasised. ${ }^{67}$ Obviously, the ius commune tradition

63 Soto, De Iustitia et Iure, fol. 5, "Neque vero est quod Theologis vitio detur, hanc sibi assumere provinciam quae Iurisperitis accommodatior videri potest: quandoquidem Canonica iura ex visceribus Theologiae prodiere: Civilia vero ex media morum Philosophia. Theologi ergo est iuris Canonici decreta ad normam Euangelicam exigere; philosophique Ciulia ex principiis philosophiae examinare."

64 Suárez, Tractatus de legibus ac deo legislatore in decem libros distributis, Prooemium, fol. 1, "Nulli mirum videri debet, si homini Theologiam profitenti leges incidant disputandae $[\ldots] . "$

65 Vitoria, De Indis prior, "Secundò dico, quòd haec determinatio non spectat ad iurisconsultos, uel saltem non ad solos illos. Quia cùm illi barbari, ut statim dicam, non essent subiecti iure humano, res illorum non sunt examinandae per leges humanas, sed diuinas, quarum iuristae non satis periti ut per se possint huiusmodi quaestiones diffinire. Nec satis scio, an unquam ad disputationem \& determinationem huius quaestionis uocati fuerint Theologi digni, qui audiri de tanta re possent. Et cum agatur de foro conscientiae, hoc spectat ad sacerdotes, id est ad ecclesiam, diffinire. unde Deutero. 17. praecipitur Regi, ut accipiat exemplar legis de manu sacerdotis" (https://id.salamanca.school/texts/ Woo13:vol.5.11?format=html $>$ :).

66 See the previous quotation of Vitoria ("vel saltem non ad solos illos") and Cano, De locis Theologicis, Libri duodecim (1563), Liber octavus, Cap. Sextum, fol. 282, "Principio enim si a Theologis animarum cura non est aliena, sed potius animas regere eorum quasi peculiare munus est, procul dubio canonici iuris scientia est illis necessaria."

67 Azpilcueta, Commentarii in tres de poenitentia distinctiones posteriores, videlicet V, VI et VII, Dist. 6., Cap. I, § caveat, n. 11, 188, "De iustitia enim Theologi generatim discere sciunt, quid illa est, \& quotuplex, an sit virtus cardinalis, an omnium moralium potissima, in qua potentia locanda, \& alia id genus, quae parum aut nihil confessario conferunt. Quod item iniustitia sit peccatum mortale, facile definire norunt. At definire, quando in iudiciis, in contractibus, in ultimis voluntatibus, et nonnunquam in delictis committatur iniustitia in casibus innumeris, qui praeter legem naturae occurrunt, vires Theologi excedit: nisi legum quoque se peritum fecerit." 
provided important auctoritates that had to be taken into account. However, as Vitoria's student and successor Melchor Cano concluded, in the end, the jurists' auctoritates were irrelevant for theologians in questions of faith and of little or no relevance with respect to norms that could be derived from the lex evangelica or from ratio. The only area where they could be of use was in the event of doubts about moribus ecclesiae \& religionis, that is to say, about what were ultimately merely functional rules. ${ }^{68}$ So one might take from this that, according to the self-perception of the actors, one needed to be a theologian to be part of the School.

Apart from the self-perception of the actors, there are good reasons for considering the School of Salamanca as a discourse community in the sense of a social group that differs from others in its specific form of discourse above all, ${ }^{69}$ as suggested some years ago by Merio Scattola. ${ }^{70} \mathrm{He}$ understood the term as denoting a community of scholarly communication whose members presented the available knowledge according to the norms of the same literary genres, used the same learned writing style, and referred to the same authorities. In fact, this brief reconstruction of some of the School's characteristics, as well as the contributions to this volume, show some of the shared dispositions such as the orientation in the Summa of Aquinas, a certain style of dealing with the auctoritates, etc. For the characteristic constellation of the authorities and styles used in such a discourse community, Scattola used the idea of a "fingerprint" which we can "take" by close reading of the texts - and, one might add today, by making use of the tools of the digital humanities. ${ }^{71}$

In view of this, we might tentatively conceptualise the School of Salamanca as an epistemic community and a community of practice that was characterised by both subjective and objective elements. As for the subjective elements, we can find a sense of belonging to a diachronic community of teachers and

68 Cano, De locis Theologicis, Libri duodecim, Liber octavus, Caput Septimum, fol. 284, "Prima conclusio: In his, quae ad fidem pertinent, iurisconsultorum auctoritate theologus non eget[...]"; fol. 285: "Secunda conclusio: In his etiam, quae ad mores pertinent, quatenus vel lex evangelica, vel ratio Philosophiae de huiusmodi praescribit, iureconsultorum auctoritas parum aut certe nihil theologo conferre potest"; fol. 285-6: "Tertia conclusio: In tertio illo genere rerum, ubi scilicet de moribus ecclesiae \& religionis institutis per leges $[\ldots]$ iurisperitorum omnium communis consensus concorsque sententia, theologo magnam fidem facere debet."

69 Pogner, "Textproduktion in Diskursgemeinschaften", 146, "Diskursgemeinschaften zeichnen sich durch unterschiedliche, spezifische Muster des Sprachgebrauchs (und des Denkens) bei der sozialen Konstruktion und Aushandlung von Bedeutung aus."

70 Scattola, Krieg des Wissens.

71 This is one of the ideas behind the publication of digital editions of key works of the School of Salamanca, see https://www.salamanca.school/en/project.html. 
pupils who recognised a founding father and who shared certain convictions about their community's identity. Part of these identity-building elements was to claim a critical spirit that privileged ratio over auctoritates and the conviction that it needed theological expertise to decide over the weightier matters of justice. Some of the members of this community might even have been convinced that one needed to be part of the Dominican Order or the Convent of San Esteban, or at least to teach theology at the University of Salamanca to be a member of the community; some of the subjective factors that make up a school may diverge to a certain degree. Others might have claimed that a basic consensus on certain topics was essential or that a certain interpretation of Thomism was needed if one wanted to belong to the community, again with slight variations. These subjective elements are relevant because the selfperception of the members of a group contributes to defining their identity irrespective of whether this self-perception corresponds to what others think or a later analysis shows. It is possible, for example, that members of a school are absolutely convinced of the uniqueness of their group, the originality of their founding father's thought, or their centrality in the process of knowledge production, without these convictions necessarily being correct. Moreover, self-perception shapes practices and so, in some cases, converts subjective elements into objective ones. For example, actors can be convinced that they are following a certain intellectual tradition and might actually develop conventions and practices that do correspond to this tradition. For these reasons, it has been suggested that we should speak of a certain habitus that characterised the members of the School of Salamanca. ${ }^{72}$

As for objective elements, the School can be seen as a discourse community recognisable by a certain constellation of the use of authorities, styles of argumentation, and certain rules of practice comprising what has been called a "theory of practice", as well as "practices of practice". In addition to this, it seems important to highlight the pragmatic dimension of the School as a place of continuous consultation and production of normative statements, be that in the confessional, personal advice, written opinions, or the treatment of practical issues of daily or political life. Even if this activity might have been more pronounced in Salamanca than in other places, it was not contingent, but responded to a historical culture of consultation and was intrinsically linked to the theologian's primary duty, the cura animarum.

In the scholarly debate on how to define the School, it has also been suggested that the centrality of certain issues - like the legitimacy of the conquest, 
or the need to reflect on the challenges that emerged as a result of the empire's expansion - could be seen as characteristics of the School. ${ }^{73}$ Others defend an institutional perspective and see the School as restricted to those who taught in Salamanca, establishing a sharp contrast between them and everyone else, whom they see as pupils or as belonging to zones of influence. These attempts to define the School by a purely institutional criterion or based on the position taken on a specific problem may be helpful for a history of the University of Salamanca or of theology. They tend, however, to isolate Salamanca from its context and underestimate the social character of knowledge production, particularly the interaction with overseas territories. ${ }^{74}$ The latter does not happen in splendid isolation but, as the last decades of critical methodological debate in the humanities have shown, as a communicative process. ${ }^{75}$ Moreover, if we take normativity to be a communicative system consisting of actors, material conditions, and established discursive styles, it is less the content but rather the mode of production that structures the system.

\section{A Knowledge-Historical Perspective on the "School of Salamanca"}

By adopting an approach taken from the history of knowledge and conceptualising the School as an epistemic community and a community of practice and thus as a participant in a communicative system - we are able to overcome the definition of the School according to its location in one place, the institutional affiliation of its members, or a particular position its members held on important issues. This has several advantages.

Firstly, it enables us to define the community according to criteria shared by the participants in the system, independent of their geographic location

73 Pereña, La Escuela de Salamanca. Proceso a la conquista de América, "La Escuela de Salamanca, notas de identidad", and "La Escuela de Salamanca y la duda indiana". On the debate and for other perspectives and further references, see Bermejo, " $¿ E s c u e l a$ de Salamanca y Pensamiento Hispánico?”; Belda Plans, "Hacia una noción crítica”; Zorroza, "Hacia una delimitación"; and Martín Gómez, "Francisco de Vitoria".

74 This has been emphasised by Brufau Prats in particular, La Escuela de Salamanca ante el descubrimiento del Nuevo Mundo, 123-124, "La Escuela salmantina no puede reducirse ni al ámbito del Estudio General de la ciudad del Tormes, ni a los coetáneos e inmediatos sucesores de Vitoria. Se extiende a las nuevas universidades que surgen en tierras americanas, como México y Lima, y a generaciones de profesores formados por los que lo fueron por Vitoria y las figuras egregias de la primera hora, como Domingo de Soto, y por los discípulos de los discípulos".

See on this, for example, Secord, "Knowledge in Transit", 662. 
in Europe, Asia, Africa, or America, and even transcending political, imperial boundaries. Moreover, as epistemic communities are not necessarily established through direct communication between their members but can be constituted by a common set of authorities, methods, or styles of thought, conceptualising the School as an epistemic community and a community of practice allows us to place authors and texts in meaningful relation to each other, irrespective of whether they had been in direct contact. Various chapters in this volume show how close the method and argumentation employed in different places was to those used in Salamanca. This was often due to direct contact or filiation. Once the former students were acting as missionaries, priests, or bishops - like Domingo de Salazar, the first bishop of Manila, to whom a number of studies in this volume are devoted (Camacho, Cobo, Moutin) -, they continued to practice what they had learned, often in contact with their alma mater, forming a community that bridged the oceans. Direct contact, however, was not necessary as long as there were other media that provided communication.

Moreover, it is often impossible to determine which particular texts or normative practices should be seen as relating to the Iberian empires' European or American territories respectively, or whether they originated in Salamanca or, for instance, in Mexico. One of the best-known examples of such difficulties in pinning down people, ideas, and texts geographically is Alonso de la Vera Cruz, aspects of whose life and works are explored by Egío, Folch, and Aspe Armella in this volume. Vera Cruz studied in Salamanca before moving to Mexico City to teach at the university there. Some of his books were printed in Mexico: his Dialectica resolutio cum textu Aristotelis in 1554 and his Speculum coniugiorum two years later. The latter, a treatise on marriage law, particularly dealt with the question of marriage among the indigenous population, as José Luis Egío shows in his contribution. The Speculum's second edition, however, was printed in Salamanca in 1562, the same year that Vera Cruz travelled to Spain where he would spend some years before returning to Mexico, each time accompanied by his huge library. There are many good reasons for counting a work like the Speculum as part of the "School of Salamanca", even if it was written thousands of kilometres away, and not just because its second edition was printed in Salamanca (others followed in Alcalá de Henares in 1572 and in Milan in 1599, both times with Apendices regarding the implications of the changes to marriage law made by the Council of Trent). The same can be said for Vera Cruz's deliberations on the legitimacy of the conquest that he wrote in Mexico which clearly followed an argumentative structure its author had learned from Vitoria, as Aspe Armella shows.

Another example of this can be seen in the manual on contract law of Tomás de Mercado, a Dominican friar who lived first in New Spain and then studied in 
Salamanca, where he also published his book. The manual was written at the request of the merchants of Seville but based on his experiences in Mexico. A further case is that of Diego de Avendaño who was born in Spain and went on to hold numerous offices in Lima, where he wrote his Thesaurus indicus. His work built on normative knowledge that was produced in Salamanca, among other places, which he translated into local realities and applied to his areas of interest. His conclusions therefore differed from those of Luis de Molina but even despite the different results, which might well have been due to his being an American - his work clearly shows that he belonged to the same epistemic community as writers from Salamanca.

In short, it seems impossible, and actually counterproductive, to identify authors like Alonso de la Vera Cruz with only one continent or place, or to classify them, in a reverse colonial mode, as fathers of colonial Latin American philosophy. They moved within an imperial space, as well as an intellectual one to whose development they themselves contributed and which actually often extended even beyond the empire's boundaries. The biography of Juan Cobo shows this very clearly: he was a Dominican who had studied in Ávila and then travelled via Mexico to the Philippines, which was then perceived as the gateway to China. Like Tomas de Mercado's Suma de Tratos y Contratos, Melchor Cano's De locis theologicis, and many other important works, Cobo's (the Shilu, for example) were printed by Matthias Gast in Salamanca. Does it make sense to separate these authors from the School simply because their institutional affiliation was different?

If we turn from the individual authors and teachers to other modalities of the production of normative knowledge, the need to open up our spatial concept of the School and also widen our understanding of it beyond a merely academic phenomenon to a community of practice becomes ever more striking. If we examine the Third Provincial Council of Mexico of 1585 , which was of paramount importance to the legal and ecclesiastical history of New Spain, ${ }^{76}$ we see that seven of the nine bishops of this vast church province had studied or taught at Salamanca, as had the Council's theological adviser and its secretary - both of whom played crucial roles in its deliberations -, and the convening archbishop, also acting as interim Viceroy at the time of the council, had been trained in Salamanca. Furthermore, we find that the answers the council gave to the requests for consultations directed to it show important similarities with those that might have been given in Salamanca, such as its replies concerning the legitimacy of the war against the indigenous groups described

Moutin, Legislar en la América hispánica. 
as the Chichimec Indians, for example. ${ }^{77}$ The council also discussed the socalled repartimientos (a system of forced labour to which part of the indigenous population was subject), trade practices that disadvantaged the indigenous population, and other trade and credit practices that possibly involved usury (usura). During these processes of formulating rulings on questions central to everyday life in New Spain, the council repeatedly consulted works of the School of Salamanca: amongst the most-cited authors were Domingo de Soto, Martín de Azpilcueta, and Juan de Medina. As far as we can reconstruct the arguments put forward in the council's deliberations, they seem to have followed a method of knowledge production that corresponded to the one used at Salamanca, just as Alonso de la Vera Cruz had done previously. Surely it is important that we integrate this mode of production of normative knowledge into our conception of the School, not least because it was this pragmatic dimension that contributed to the presence, localisation, and massive cultural translation of the School's juridical-political language far beyond Salamanca. If we consider normativity as a communicative system comprising different actors and if we leave aside the characterisation of the School as a purely academic enterprise (which was the result of path dependencies stemming from the 19th-century beginnings of its historiography), we cannot ignore this mode of production of normative knowledge.

Opening up our understanding of the School in this way, we can also see that there were many nodes in the web of knowledge production and that information flowed through this web in all directions, not just from Salamanca to the "peripheries" or between universities. Priests and missionaries, theologians and canonists, and even jurists, imperial officers, and merchants, were part of an epistemic community and a community of practice that was not restricted to certain cities, regions, or institutions. Books, letters, reports, and also people circulated across vast distances. ${ }^{78}$ They all contributed to translating the legal-political language produced in Salamanca - and, as we saw, elsewhere as well - into similar, or sometimes radically different, local contexts. Some of the problems they dealt with had already occupied theologians and jurists in Europe and others arose from local circumstances, but whether familiar or unprecedented, each individual case had to be decided according to its unique context and drawing on the same authorities, the same theory of practice, and perhaps even employing the same practices. With such innumerable and individual decisions and judgments, countless agents from all corners

77 For a more detailed discussion on this, see Duve, "Salamanca in Amerika".

78 On the presence of pragmatic, moral-theological literature in different parts of colonial Latin America, see the contributions in Duve and Danwerth, Knowledge of the pragmatici. 
of the empire contributed to the development of a theologically founded normative knowledge. Of course, these processes could shift the meaning of terms and the language quickly grew beyond the vocabulary originally developed in Salamanca. However, Salamanca did not exist in isolation: it was a hub of knowledge that continuously absorbed knowledge from other areas and integrated it into its own discussions and deliberations, thus adding to the transformation of knowledge. Salamanca was never "pure".

Conceptualising the School as an epistemic community and a community of practice that was not necessarily limited to the physical space of Salamanca also enables us to create a comparative framework for setting the authors from Salamanca into the context of both preceding and subsequent writers, even those from the Protestant world. As scholars of all Christian confessions initially built on a common tradition, it should come as no surprise to find that discussions in reformed Wittenberg and those in Salamanca on the right of Protestant rulers to resist Emperor Charles v used similar argumentative forms and started from the same auctoritates - albeit with very different results. ${ }^{79}$ In an analogous manner, it has been shown that Philipp Melanchthon's Loci communes shared many characteristics with the natural law theory of the School of Salamanca. ${ }^{80}$ And, as Scattola has argued, Johannes Althusius built in many ways on what Philipp Melanchthon, and Aquinas before him, had established in his own theory of natural law. ${ }^{81}$ In his arguments for the United Provinces of the Netherlands' right to resist Philip II, Johannes Althusius - like Hugo Grotius and other Reformed scholars - turned the Spaniards' own weapons against them. ${ }^{82}$ Ditlev Tamm has suggested that certain aspects of the 16th-century Danish theologian Niels Hemmingsen's work could fruitfully be interpreted with the School of Salamanca in mind. ${ }^{83}$ Recent research has shed new light on Lutheran casuistry and Lutheran theology and contract law and so invites us to compare techniques of producing normative knowledge beyond the confessional sphere. ${ }^{84}$ The same might be true of the works of earlier scholars such as Stanisław of Skarbimierz (1360-1431) and Paweł Włodkowicz, Paulus Vladimiri (1370-1436), who both worked at the University of Krakow. ${ }^{85}$ The latter's treatise against the haeresis

79 See also Scattola, "Widerstand und Naturrecht im Umkreis von Philipp Melanchthon".

8o Scattola, "Notitia naturalis de Deo et de morum gubernatione".

81 Scattola, "Johannes Althusius und das Naturrecht".

82 Reibstein, Johannes Althusius als Fortsetzer der Schule von Salamanca.

83 Tamm, "Rechtswissenschaft im Dienste der Theologie".

84 Mayes, Counsel and Conscience; Astorri, Lutheran Theology and Contract Law.

85 Belch, Paulus Vladimiri and his doctrine. 
Prussiana in particular has often been linked to the School of Salamanca's thought, most recently by Alfred Dufour. ${ }^{86}$

Of course, these authors were not part of the "School of Salamanca" in the institutional interpretation of the term. However, they might have shared characteristics that distinguished them from their contemporary epistemic communities and might thus be more fruitfully seen in a joint context with authors from Salamanca or Mexico than, for example, with writers from their more immediate local or regional surroundings. The challenge for future research lies in establishing a set of subjective and objective criteria, far more detailed than those that have been sketched out here, through a close reading of the texts and their contexts, that helps us to bring different actors of the communicative system into a joint picture, despite the fact that they came from different confessions, traditions, and continents.

The School of Salamanca as a Case of Global Knowledge Production

Why, however, a "global" production of knowledge? Research into global history in the last decades has claimed that the increasing expansion of colonial spheres of influence and interconnections cannot simply be conceived of as a process of ideas developed in Europe being disseminated to the rest of the world. It has exposed the Eurocentric assumptions underlying simplistic narratives of European originals being copied in the peripheries, or exerting "influence" there. It has made us increasingly aware of the interconnectedness of different world regions and the deep entanglements between different places. Not least studies from the emerging field of the history of knowledge have uncovered the social and communicative nature of knowledge and the importance of (cultural) translations and the semantic shifts they produced.

The approach suggested here wants to take these claims seriously. It is based on the legal-theoretical assumption that normativity has to be understood as a communicative system, a cultural practice that can be observed in many localities, which is built on material conditions and discursive styles and which continuously transforms itself. Seeing the School of Salamanca as a cultural practice thus replaces a paradigm based on a narrow European understanding of the history of the School as a contribution to European scholarship - such as Hinojosa's and his followers' - by attempting to understand the School as 
an epistemic community and a community of practice that cannot be limited to one continent but which was structurally without geographic limitation. Its scope depended on the range of circulation of the normative knowledge including, of course, practical normative knowledge - of which it consisted.

Another important aim of framing our analysis of the School as communicative practice lies in the fact that the development of knowledge in the field of normativity cannot be reduced to the history of "learned" knowledge without taking the practical dimension as well as the practices in a praxeological sense into account. The perspective suggested here wants to overcome the circular argumentation of constructing the School as a purely academic phenomenon according to European standards. Because there were nearly no universities of this kind outside Europe, it is not surprising that, when looking through the lens of European standards, one only finds what looks like faint copies of the originals. Understanding the School as communicative practice shows how historically incorrect the picture of a solipsistic school acting as the theory-producing and exporting centre, which communicates knowledge to its spheres of influence without being affected by what came from them in turn, is. Instead, it reveals a global space filled with epistemic communities and communities of practice that continuously produced normative knowledge in different formats and thus contributed to the polycentric development of a legal-political language that has not only one dimension - the academic one - and not only one centre, but many.

It may even be possible to map flows of communications, the nodes in the web, some bigger, some smaller. On such a map, particular regions or places such as, for example, in the Iberian Peninsula - may be revealed as the location of important clusters. It might also show where similar processes of knowledge production occurred on both sides of a continental or even confessional boundary - or where, by contrast, they clearly differed. Perhaps we would also find on it something like a "colonial scholasticism" as a clearly distinguishable epistemic community. ${ }^{87}$ On this map, Salamanca, Mexico, and Manila might suddenly lie very close together, closer than Madrid and Milan, for example. In all of these locations, normative knowledge was produced under very specific practical conditions, localised, and translated into the context of each individual case. The resulting normative statements became part of the huge pool of normative knowledge that could be drawn on in future. This process led to the emergence of a body of normative knowledge that provided the world - for

87 This would be different from taking the colonial setting as a starting point, see, for example, Beuchot, Ensayos sobre escolástica hispana; Culleton and Pich, "Scholastica colonialis"; and Restrepo, "Colonial Thought". 
better or worse - with important elements for the formation of "legal imperialism", and also for a "universal code" of legality or even a "cosmopolitan law", to which we too continually contribute up to the present day.

\section{Bibliography}

\section{Printed Sources}

Azpilcueta, Martín de, Commentarii in tres de poenitentia distinctiones posteriores, videlicet V, VI et VII, Lugduni 1569: Petrus Fradinus.

Cano, Melchor, De locis Theologicis, Libri duodecim, Salmanticae 1563: Mathias Gast.

Soto, Domingo de, De Iustitia et Iure, Salmanticae 1556: Andrea de Portonaris.

Suárez, Francisco, Tractatus de legibus ac deo legislatore in decem libros distributis, Conimbricae 1612: Diego Gómez de Loureiro.

Vitoria, Francisco de, "Disensiones del reverendo padre maestro fray Francisco de Vitoria sobre ciertos tratos de mercaderes", in Zorroza Huarte, María Idoya (ed.), Francisco de Vitoria. Contratos y usura, Pamplona 2006, 301-306.

Vitoria, Francisco de, "Comentario a la Ia Pars de la Summa Theologiae", transcribed in: Langella, Simona, La ciencia teológica de Francisco de Vitoria y la Summa Theologiae de Santo Tomás de Aquino en el siglo XVI a la luz de textos inéditos, Salamanca 2013, App. v.1., 262-415.

Vitoria, Francisco de, [Preface to the edition of Aquinas' II-IIae, Paris, 1512: Claudio Chevalon], transcribed in: Langella, Simona, La ciencia teológica de Francisco de Vitoria y la Summa Theologiae de Santo Tomás de Aquino en el siglo XVI a la luz de textos inéditos, Salamanca 2013, App. i., 102-109.

Vitoria, Francisco de, De potestate civili, in: Relectiones Theologicae XII (2018 [1557]), vol. 1, in: The School of Salamanca. A Digital Collection of Sources <https://id.salamanca.school/texts/Woo13:vol1.3?format=html>.

Vitoria, Francisco de, De Indis prior, in: Relectiones Theologicae XII (2018 [1557]), vol. 1, in: The School of Salamanca. A Digital Collection of Sources <https://id.salamanca. school/texts/Woor3:vol.5?format=html>.

\section{Literature}

Abel, Günter, "Systematic Knowledge Research. Rethinking Epistemology", in Sandkühler, Hans Jörg (ed.), Wissen. Wissenskulturen und die Kontextualität des Wissens, Frankfurt 2014, 17-37.

Abulafia, David, Discovery of Mankind. Atlantic Encounters in the Age of Columbus, New Haven (CT) 2009.

Alonso Getino, Luis G., El Maestro Fr. Francisco de Vitoria. Su vida, su doctrina e influencia, Madrid 1930. 
Alonso Romero, María Paz, Salamanca, escuela de juristas. Estudios sobre la enseñanza del derecho en el Antiguo Régimen, Madrid 2012.

Anghie, Antony, Imperialism, Sovereignty and the Making of International Law, Cambridge 2005 .

Astorri, Paolo, Lutheran Theology and Contract Law in Early Modern Germany (ca. 15201720), Paderborn 2019.

Barreto Xavier, Ângela, Frederico Palomo and Roberta Stumpf (eds.), Monarquias Ibéricas em Perspectiva Comparada (Sécs. XVI-XVIII). Dinâmicas Imperiais e Circulação de Modelos Administrativos, Lisboa 2018.

Barrientos García, José, "La Escuela de Salamanca: desarrollo y caracteres", in Ciudad de Dios: Revista Agustiniana 208:2 (1995), 1041-1079.

Barrientos García, José, “Los Tratados “De Legibus” y “De Iustitia et Iure” en la Escuela de Salamanca de los siglos XVI y XVII", in Salamanca 47 (2001), 371-415.

Barrientos García, José, "La teología, siglos XVI-XVII", in Rodríguez-San Pedro Bezares, Luis Enrique (ed.), Historia de la Universidad de Salamanca. Saberes y confluencias, (3/1), 1 ed., Salamanca 2002, 203-250.

Barrientos García, José, Repertorio de moral económica (1526-1670). La Escuela de Salamanca y su proyección, 1 ed., Pamplona 2011.

Barrientos García, José, La Facultad de Teología de la Universidad de Salamanca a través de los Libros de Visita de Cátedras (1560-1641), Madrid 2018.

Bataillon, Marcel, Erasme et l'Espagne. Recherches sur l'histoire spirituelle duXVIe siècle, Paris, Bordeaux 1937.

Belch, Stanislaus F., Paulus Vladimiri and his doctrine concerning international law and politics, (2), London, The Hague, Paris 1965.

Belda Plans, Juan, La Escuela de Salamanca y la renovación de la teología en el siglo XVI, Madrid 2000.

Belda Plans, Juan, "Hacia una noción crítica de la "Escuela de Salamanca", in Scripta Theologica 31:2 (1999), 367-411 (dadun.unav.edu/bitstream/10171/13357/1/ST_XXXI2_o3.pdf).

Belda Plans, Juan, "Teología práctica y Escuela de Salamanca del Siglo XVI", in Cuadernos Salmantinos de Filosofía 30 (2003), 461-489.

Beltrán de Heredia, Vicente, Los manuscritos del maestro fray Francisco de Vitoria, O.P. Estudio critico de introducción a sus lecturas y relecciones, Madrid 1928.

Bermejo, Ignacio Jericó, “¿Escuela de Salamanca y Pensamiento hispánico? Ante una propuesta", in Salmanticensis 59:1 (2012), 83-114.

Beuchot, Mauricio, Ensayos sobre escolástica hispana, Pamplona 2013.

Bragagnolo, Manuela, "Managing Legal Knowledge in Early Modern Times. Martín de Azpilcueta's Manual for Confessors and the Phenomenom of "Epitomisation"”, in Duve, Thomas and Otto Danwerth (eds.), Knowledge of the Pragmatici: Legal and Moral Theological Literature and the Formation of Early Modern Ibero-America, Leiden 2020, 187-242 (https://doi.org/10.1163/9789004425736_oo7). 
Braun, Harald E. and Paolo Astorri (eds.), A Companion to the Spanish Scholastics, Leiden (forthcoming).

Brett, Annabel, "Sources in the Scholastic Legacy: The (re)Construction of the in the Second Scholastic", in Besson, Samantha and Jean d'Aspremont (eds.), The Oxford Handbook of the Sources of International Law, Oxford, New York (NY) 2017, 64-82 (http://doi.org/10.1093/law/9780198745365.003.0003).

Brufau Prats, Jaime, La Escuela de Salamanca ante el descubrimiento del Nuevo Mundo, Salamanca 1989 .

Bouza, Fernando and Pedro Cardim, Antonio Feros (eds.), The Iberian World 1450-1820, New York 2020.

Burke, Peter, What is the History of Knowledge?, Cambridge 2015.

Carabias Torres, Ana Maria, "La Escuela de Salamanca. Perspectivas de investigación", in Salamanca Working Papers Series o3 (2015) (urn:nbn:de:hebis:30:3-376105).

Cerezo, Prometeo, "Influencia de la Escuela de Salamanca en el pensamiento universitario americano", in Ramos, Demetrio, Antonio García y García, Isacio Pérez and Manuel Lucena (eds.), La ética en la conquista de América, Madrid 1984, 551-596.

Cetina Knorr, Karin, "Epistemic cultures", in Restivo, Sal (ed.), Science, Technology, and Society, Oxford 2005 .

Culleton, Alfredo Santiago and Roberto Hofmeister Pich, "Scholastica colonialis - Reception and Development of Baroque Scholasticism in Latin-American Countries, 16th-18th centuries: The Two First Years of a Project", in Bulletin de Philosophie Médiévale 54 (2012), 21-42.

Daston, Lorraine, "The History of Science and the History of Knowledge", in Know 1:1 (2017), 131-154 (https://doi.org/10.1086/691678).

Decock, Wim, “From Law to Paradise: Confessional Catholicism and Legal Scholarship", in Rechtsgeschichte 18 (2011), 12-34.

Decock, Wim, Theologians and Contract Law. The Moral Transformation of the Ius Commune (ca.1500-1650), Leiden 2013.

Decock, Wim and Christiane Birr, Recht und Moral in der Scholastik der Frühen Neuzeit 1500-1750, Berlin, Boston (MA) 2016 (https://doi.org/10.1515/9783110379686).

Dufour, Alfred, “Droit international et chrétienté: des origines espagnoles aux origines polonaises du droit international. Autour du sermon De bellis justis du canoniste polonais Stanislas de Skarbimierz (136o-1431)", in Dupuy, Pierre-Marie and Vincent Chetail (eds.), The Roots of International Law. Liber Amicorum Peter Haggenmacher, Leiden - Boston (MA) 2014, 95-119 (https://doi.org/10.1163/9789004261655_005).

Duve, Thomas, “ ¿"La mayor burla del mundo"? Francisco de Vitoria y el dominium del Papa sobre los bienes de los pobres", in Cruz Cruz, Juan (ed.), Ley y dominio en Francisco de Vitoria, Pamplona 2008, 93-106.

Duve, Thomas, "Von der Europäischen Rechtsgeschichte zu einer Rechtsgeschichte Europas in globalhistorischer Perspektive", in Rechtsgeschichte - Legal History 20 (2012), 18-71 (https://doi.org/10.12946/rg2o/o18-o71). 
Duve, Thomas, "Salamanca in Amerika", in Zeitschrift der Savigny-Stiftung für Rechtsgeschichte. Germanistische Abteilung 132 (2015), 116-151 (https://doi.org/ 10.7767/zrgga-2015-0108).

Duve, Thomas, "Was ist „Multinormativität"? - Einführende Bemerkungen”, in Rechtsgeschichte - Legal History 25 (2017), 88-101 (https://doi.org/10.12946/rg25/ o88-101).

Duve, Thomas, "Global Legal History: Setting Europe in Perspective”, in Pihlajamäki, Heikki, Markus D. Dubber and Mark Godfrey (eds.), The Oxford Handbook of European Legal History, Oxford, New York (NY) 2018, 115-140 (https://doi.org/ 10.1093/oxfordhb/9780198785521.013.5).

Duve, Thomas, "La Escuela de Salamanca: ¿un caso de producción global de conocimiento? Consideraciones introductorias desde una perspectiva histórico-jurídica y de la historia del conocimiento", The School of Salamanca Working Paper Series 2 (2018), (urn:nbn:de:hebis:30:3-376152).

Duve, Thomas, "Legal traditions. A dialogue between Comparative Law and Comparative Legal History", in Comparative Legal History 6:1 (2018), 15-33 (https:// doi.org/10.1080/2049677X.2018.1469271).

Duve, Thomas, "Rechtsgeschichte und Rechtsräume: wie weit reicht die Schule von Salamanca?", in Luts-Sotaak, Marju and Frank Schäfer (eds.), Recht und Wirtschaft in Stadt und Land - Law and Economic in Urban and Rural Environment. Neunter Rechtshistorikertag im Ostseeraum/ gth Conference in Legal History in the Baltic Sea Area 16.-20. Mai 2018 in Tallinn, Sagadi und Tartu, Estland 16-20 May 2018 in Tallinn, Sagadi and Tartu, Estonia, Bern 2020, 51-72, (https://doi.org/10.3726/ b16496).

Duve, Thomas and Otto Danwerth (eds.), Knowledge of the pragmatici:Legal and Moral Theological Literature and the Formation of Early Modern Ibero-America, (1), Leiden 2020 (https://doi.org/10.1163/9789004425736).

Duve, Thomas, "Pragmatic Normative Literature and the Production of Normative Knowledge in the Early Modern Iberian Empires (16th-17th Centuries)", in Duve, Thomas and Otto Danwerth (eds.), Knowledge of the pragmatici: Legal and Moral Theological Literature and the Formation of Early Modern Ibero-America, (1), Leiden 2020, 1-39 (https://doi.org/10.1163/9789004425736_oo2).

Duve, Thomas, "The School of Salamanca: a legal historical perspective", in Braun, Harald E. and Paolo Astorri (eds.), A Companion to Spanish Scholastics, Leiden forthcoming.

Egío Garcia, José Luis and Christiane Birr, "Alonso de Cartagena y Juan López de Palacios Rubios. Dilemas suscitados por las primeras conquistas atlánticas en dos juristas salmantinos (1436-1512)", in Azafea. Revista de Filosofía 20 (2018), 9-36.

Egío Garcia, José Luis and Christiane Birr, "Before Vitoria: Expansion into Heathen, Empty or Disputed Lands in Late-Mediaeval Salamanca Writings and Early 
16th-Century Juridical Treatises", in Tellkamp, Jörg Alejandro (ed.), A Companion to Early Modern Spanish Imperial Political and Social Thought, Leiden, Boston (MA) 2020, 53-77.

Fernández-Armesto, Felipe, Before Columbus. Exploration and Colonization from Mediterranean to the Atlantic, 1229-1492, 3 ed., Philadelphia (PA) 1994.

Folgado, Avelino, "Los tratados De legibus y De iustitia et iure en los autores españoles del siglo XVI y primera mitad del XVII", in La Ciudad de Dios 72:3 (1959), 275-302.

González Polvillo, Antonio, El gobierno de los otros. Confesión y control de la conciencia en la España Moderna, Sevilla 2010.

Gordley, James, The Philosophical Origins of Modern Contract Doctrine, Oxford, New York (NY) 1991.

Grabmann, Martin, "Die Disputationes metaphysicae des Franz Suarez in ihrer methodischen Eigenart und Fortwirkung", in Six, Karl, Martin Grabmann, Franz Hatheyer, Andreas Inauen and Josef Biederlack (eds.), P. Franz Suárez S. J.: Gedenkblätter zu seinem dreihundertjährigen Todestag (25. September 1617). Beiträge zur Philosophie des P. Suárez, Innsbruck 1917, 29-73.

Grice-Hutchinson, Marjorie, "El concepto de la Escuela de Salamanca: sus orígenes y su desarrollo", in Revista de Historia Económica 7:2 (1989), 21-26 (https://doi.org/ 10.1017/So212610900001798=).

Hespanha, António Manuel, "Southern Europe (Italy, Iberian Peninsula, France)", in Pihlajamäki, Heikki, Markus Dubber and Mark Godfrey (eds.), The Oxford Handbook of European Legal History, Oxford 2018, 332-356.

Hinojosa y Naveros, Eduardo de, Discursos leídos ante la Real Academia de la Historia en la recepción pública de D. Eduardo de Hinojosa el día 10 de marzo de 1889, Madrid 1889.

Jansen, Nils, Theologie, Philosophie und Jurisprudenz in der spätscholastischen Lehre von der Restitution. Außervertragliche Ausgleichsansprüche im frühneuzeitlichen Naturrechtsdiskurs, Tübingen 2013.

Kohler, Josef, "Die spanische Naturrechtslehre des 16. und 17. Jahrhunderts", in Archiv für Rechts- und Wirtschaftsphilosophie 10:3 (1917), 235-263 (http://www.jstor.org/stable/23683576).

Koskenniemi, Martti, The Gentle Civilizer of Nations. The Rise and Fall of International Law 1870-1960, Cambridge 2002.

Koskenniemi, Martti, "Empire and International Law: The Real Spanish Contribution”, in University of Toronto Law Journal 61:1 (2011), 1-36 (10.3138/utlj.61.1.001).

Koskenniemi, Martti, "Vitoria and Us. Thoughts on Critical Histories of International Law”, in Rechtsgeschichte - Legal History 22 (2014), 119-138 (https://doi.org/10.12946/ $\operatorname{rg} 22 / 119-138)$.

Lalinde Abadia, Jesús, "Anotaciones historicistas al iusprivatismo de la segunda escolastica", in Grossi, Paolo (ed.), La Seconda scolastica nella formazione del diritto privato moderno. Incontro di studio, Firnze 16-19 ottobre 1972, Milano 1973, 303-375. 
Lalinde Abadia, Jesús, “ Una ideología para un sistema (La simbiosis histórica entre el iusnaturalismo castellano y la Monarquía Universal)", in Quaderni fiorentini per la storia del pensiero giuridico moderno 8 (1979), 62-156.

Langella, Simona, La ciencia teológica de Francisco de Vitoria y la Summa Theologiae de Santo Tomás de Aquino en el siglo XVI a la luz de textos inéditos, Salamanca 2013.

Mahoney, John, The Making of Moral Theology. A Study of the Roman Catholic Tradition, Reprint ed., Oxford, New York (NY) 1989.

Mandrella, Isabelle, "Der Dekalog als Systematisierungsschlüssel angewandter Ethik im 13. und 14. Jahrhundert", in Korff, Wilhelm and Markus Vogt (eds.), Gliederungssysteme angewandter Ethik, Freiburg, Basel, Wien 2016, 228-255.

Marcocci, Giuseppe, "Conscience and Empire: Politics and Moral Theology in the Early Modern Portuguese World", in Journal of Early Modern History 18 (2014), 473-494.

Martín Gómez, María, "Francisco de Vitoria y la Escuela Ibérica de la Paz", in Revista Portuguesa de Filosofía 75:2 (2019), 861-89o, (https://doi.org/10.1799o/RPF/2019_75_ 2_o861).

Martínez Neira, Manuel and Pablo Ramírez Jerez, Hinojosa en la Real Academia de Ciencias Morales y Políticas, Madrid 2018.

Martínez Peñas, Leandro, El confesor del rey en el Antiguo Régimen, Madrid 2006.

Mayes, Benjamin T. G., Counsel and Conscience. Lutheran Casuistry and MoralReasoning After the Reformation, Göttingen 2011.

Möllers, Christoph, Die Möglichkeit der Normen. Über eine Praxis jenseits von Moralität und Kauslität, Berlin 2015.

Moutin, Osvaldo Rodolfo, Legislar en la América hispánica en la temprana edad moderna. Procesos y características de la producción de los Decretos del Tercer Concilio Provincial Mexicano (1585), Frankfurt am Main 2016.

Muldoon, James (ed.), Bridging the Medieval-Modern Divide. Medieval Themes in the World of the Reformation, Farnham 2013.

Müller-Wille, Staffan, Carsten Reinhardt and Marianne Sommer, "Wissenschaftsgeschichte und Wissensgeschichte", in Müller-Wille, Staffan, Carsten Reinhardt and Marianne Sommer (eds.), Handbuch Wissensgeschichte, Stuttgart 2017, 2-18.

Müller, Sigrid, "Die Bedeutung des Dekalogs für die Entwicklung der neuzeitlichen Moraltheologie im Zeichen der Kasuistik", in Korff, Wilhelm und Markus Vogt (ed.), Gliederungssysteme Angewandter Ethik. Ein Handbuch, Freiburg, Basel, Wien 2016, $256-283$.

Neumann, Birgit, “Kulturelles Wissen”, in Nünning, Ansgar (ed.), Metzler Lexikon Literaturund Kulturtheorie. Ansätze-Personen-Grundbegriffe, 5 ed., Stuttgart, Weimar 2013, 811.

Nys, Ernest, Le droit de la guerre et les précurseurs de Grotius, Brussels, Leipzig, London, New York (NY), Paris 1882. 
O'Banion, Patrick J., The Sacrament of Penance and Religious Life in Golden Age Spain, University Park (PA) 2012.

Olmedo Bernal, Santiago, El dominio del Atlántico en la Baja Edad Media. Los títulos jurídicos de la expansión peninsular hasta el Tratado de Tordesillas, Valladolid 1995.

Pagden, Anthony, "The Christian Tradition", in Buchanan, Allen and Margaret Moore (eds.), States, Nations and Borders. The Ethics of Making Boundaries, Cambridge, New York (NY) 2003, 103-126.

Pena González, Miguel Anxo, Aproximación bibliográfica a la $(s)$ «Escuela $(s)$ de Salamanca», Salamanca 2008.

Pereña, Luciano, "La Escuela de Salamanca y la duda indiana", in Ramos, Demetrio, Antonio García y García, Isacio Pérez and Manuel Lucena (eds.), La ética de la conquista de América, Madrid 1984, 291-344.

Pereña, Luciano, La Escuela de Salamanca. Proceso a la conquista de América, Salamanca 1986.

Pereña, Luciano, “La Escuela de Salamanca, notas de identidad”, in Gómez Camacho, Francisco and Ricardo Robledo (eds.), El pensamiento económico en la Escuela de Salamanca. Una visión multidisciplinar. Seminarios celebrados en Salamanca en 1992, 1993 y 1995 organizados por la Fundación Duques de Soria y dirigidos por el Profesor Ernest Lluch, Salamanca 1998, 43-64.

Pérez Voituriez, Antonio, Problemas jurídicos internacionales de la conquista de Canarias, Las Palmas de Gran Canaria 1958.

Pogner, Karl-Heinz, “Textproduktion in Diskursgemeinschaften”, in Jakobs, Eva-Maria, Dagmar Knorr and Karl-Heinz Pogner (eds.), Textproduktion: HyperText, Text, KonText, Frankfurt am Main 1999, 145-158.

Quantin, Jean-Louis, “A propos des premières Summae confessorum. Théologie et droit canonique", in Recherches de théologie ancienne et médiévale 26 (1959), 264-306.

Quantin, Jean-Louis, "Catholic Moral Theology, 1550-180o", in Lehner, Ulrich L., Richard A. Muller and Anthony G. Roeber (eds.), The Oxford Handbook of Early Modern Theology, 16oo-180o, New York (NY) 2016, 119-134.

Ramírez Santos, Celia Alejandra and José Luis Egío, Conceptos, autores, instituciones. Revisión crítica de la investigación reciente sobre la Escuela de Salamanca (2008-19) y bibliografía multidisciplinar (con Prefacio de Thomas Duve), Madrid 2020 (http:// hdl.handle.net/10016/3010o).

Ramos, Demetrio (ed.), Francisco de Vitoria y la Escuela de Salamanca: La ética en la Conquista de América, Madrid 1984.

Rasilla del Moral, Ignacio de la, In the Shadow of Vitoria. A History of International Law in Spain (1770-1953), Leiden 2017.

Rauschenbach, Sina and Christian Windler (eds.), Reforming Early Modern Monarchies. The Castilian Arbitristas in Comparative European Perspectives, Wiesbaden 2016. 
Reibstein, Ernst, Johannes Althusius als Fortsetzer der Schule von Salamanca. Untersuchungen zur Ideengeschichte des Rechtsstaates und zur altprotestantischen Naturrechtslehre, Karlsruhe 1955.

Renn, Jürgen (ed.), The Globalization of Knowledge in History, Berlin 2012 (http:// edition-open-access.de/studies/1/index.html).

Renn, Jürgen and Malcolm H. Hyman, "The Globalization of Knowledge in History: An Introduction”, in Renn, Jürgen (ed.), The Globalization of Knowledge in History, Berlin 2012, 15-44 (http://www.edition-open-access.de/media/studies/1/5/Studiesich1. pdf).

Renn, Jürgen, "The Globalization of Knowledge in History and its Normative Challenges", in Rechtsgeschichte - Legal History 22 (2014), 52-6o (https://doi.org/ 10.12946/rg22/052-06o).

Renn, Jürgen, "From the History of Science to the History of Knowledge - and Back", in Centaurus 57:1 (2015), 37-53 (https://doi.org/10.1111/160o-0498.12075).

Restrepo, Luis Fernando, “Colonial Thought", in Nuccetelli, Susana (ed.), A Companion to Latin American Philosophy, Chichester 2010, 36-52.

Rodríguez-San Pedro Bezares, Luis E. and Juan Luis Polo Rodríguez (eds.), La Universidad de Salamanca y sus confluencias americanas, Salamanca 2008.

Rodríguez-San Pedro Bezares, Luis E. and Juan Luis Polo Rodríguez, "Bibliografía sobre la Universidad de Salamanca (180o-2007)", in Rodríguez-San Pedro Bezares, Luis E. and Juan Luis Polo Rodríguez (eds.), Historia de la Universidad de Salamanca. Vestigios y entramados, (4), 1 ed., Salamanca 2009, 639-836.

Scarfi, Juan Pablo, The Hidden History of International Law in the Americas. Empire and Legal Networks, New York (NY) 2017.

Scattola, Merio, “'Notitia naturalis de Deo et de morum gubernatione'. Die Naturrechtslehre Philipp Melanchthons und ihre Wirkung im 16. Jahrhundert", in Bauer, Barbara (ed.), Melanchthon und die Marburger Professoren, Marburg 1999, $865-882$.

Scattola, Merio, "Johannes Althusius und das Naturrecht des 16. Jahrhunderts", in Carney, Frederick S., Heinz Schilling and Dieter Wyduckel (eds.), Jurisprudenz, Politische Theorie und Politische Theologie. Beiträge des Herborner Symposions zum 40o. Jahrestag der Politica des Johannes Althusius (1603-2003), Berlin 2004, 371-396.

Scattola, Merio, "Widerstand und Naturrecht im Umkreis von Philipp Melanchthon", in Schorn-Schütte, Luise (ed.), Das Interim 1548/50. Herrschaftskrise und Glaubenskonflikt, Gütersloh 2005, 459-487.

Scattola, Merio, Krieg des Wissens - Wissen des Krieges. Konflikt, Erfahrung und System der literarischen Gattungen am Beginn der Frühen Neuzeit, Padova 2006.

Scattola, Merio, "Domingo de Soto e la fondazione della scuola di Salamanca", in Veritas 54:3 (2009), 52-70 (http://revistaseletronicas.pucrs.br/ojs/index.php/veritas/article/view/6416/4682). 
Scattola, Merio, "Das Ganze und die Teile. Menschheit und Völker in der naturrechtlichen Kriegslehre von Francisco de Vitoria”, in Brieskorn, Norbert and Gideon Stiening (eds.), Francisco de Vitorias >De Indis` in interdisziplinärer Perspektive, Stuttgart 2011.

Scattola, Merio, "Die Systematik des Natur- und Völkerrechts bei Francisco de Vitoria", in Bunge, Kirstin, Anselm Spindler and Andreas Wagner (eds.), Die Normativität des Rechts bei Francisco de Vitoria, Stuttgart 2011, 351-391.

Schmutz, Jacob, "From Theology to Philosophy: The Changing Status of the Summa Theologiae, 1500-2000", in Hause, Jeffrey (ed.), Aquinas's Summa Theologiae. A Critical Guide, Cambridge, New York (NY) 2018, 221-241 (https://doi.org/10.1017/ 9781316271490).

Schüßler, Rudolf, "Meinungspluralismus in Moraltheologie und Kasuistik seine Grundlegung im Barock", in Korff, Wilhelm and Markus Vogt (eds.), Gliederungssysteme angewandter Ethik. Ein Handbuch. Nach einem Projekt von Wilhelm Korff, Freiburg, Basel, Wien 2016, 284-307.

Scott, James Brown, The Catholic Conception of International Law. Francisco de Vitoria, Founder of the Modern Law of Nations. Francisco Suarez, Founder of the Modern Philosophy of Law in General and in Particular of the Laws of Nations. A Critical Examination and a Justified Appreciation, Washington, D.C. 1934.

Scott, James Brown, The Spanish Origin of International Law. Francisco de Vitoria and his Law of Nations, Oxford 1934.

Secord, James A., "Knowledge in Transit", in Isis 95:4 (2004), 654-672 (https://doi.org/ 10.1086/430657).

Sosa Mayor, Igor, El noble atribulado. Nobleza y teología moral en la Castilla moderna (1550-1650), Madrid 2018.

Tamm, Ditlev, "Rechtswissenschaft im Dienste der Theologie. Zur Stellung der Rechtswissenschaft an den nordischen Universitäten im 17. Jahrhundert", in Dübeck, Inger, Bertil Frosekk, Jens Christian V. Johanse, Jens Ulf Jørgensen and Ditlev Tamm (eds.), Med lov skal land bygges og andre retshistoriske afhandlinger, Købnhavn 1989, 185-195.

Tellkamp, Jörg A., "Vitorias Weg zu den legitimen Titeln der Eroberung Amerikas", in Bunge, Kirstin, Anselm Spindler and Andreas Wagner (eds.), Die Normativität des Rechts bei Francisco de Vitoria, Stuttgart 2011, 147-170.

Tellkamp, Jörg A. (ed.), A Companion to Early Modern Spanish Imperial Political and Social Thought, Leiden, Boston (MA) 2020.

Theiner, Johann, Die Entwicklung der Moraltheologie zur eigenständigen Disziplin, Regensburg 1970.

Thieme, Hans, "Natürliches Privatrecht und Spätscholastik", in Zeitschrift der SavignyStiftung für Rechtsgeschichte. Germanistische Abteilung 70:1 (1953), 230-266 (https:// doi.org/10.7767/zrgga.1953.70.1.230). 
Vereecke, Louis, Storia della teologia morale moderna, (2), Roma 1973.

Vidal, Marciano, Historia de la teología moral. La moral en la edad moderna (ss. XVXVI). Humanismo y Reforma, (4/1), Madrid 2012.

Villaverde, María José and Francisco Castilla Urbano (eds.), La sombra de la leyenda negra, Madrid 2016.

Wagner, Andreas, "Zum Verhältnis von Völkerrecht und Rechtsbegriff bei Francisco de Vitoria", in Bunge, Kirstin, Anselm Spindler and Andreas Wagner (eds.), Die Normativität des Rechts bei Francisco de Vitoria, Stuttgart 2011, 255-286.

Wehling, Peter, "Wissensregime", in Schützeichel, Rainer (ed.), Handbuch Wissenssoziologie und Wissensforschung, Konstanz 2007, 704-712.

White, James Boyd, "Legal Knowledge”, in Harvard Law Review 115:5 (2002), 1396-1431 (https://doi.org/10.2307/1342550).

Zorroza Huarte, Maria Idoya, "Hacia una delimitación de la Escuela de Salamanca", in Revista Empresa y Humanismo 16:1 (2013), 53-72. 